PRICING DECISIONS IN FRANCHISED

CHAINS: A LOOK AT THE RESTAURANT

AND FAST-FOOD INDUSTRY

Francine Lafontaine

Working Paper 5247

\author{
NATIONAL BUREAU OF ECONOMIC RESEARCH \\ 1050 Massachusetts Avenue \\ Cambridge, MA 02138 \\ September 1995
}

This paper has benefitted from the comments of Frank Fisher, Sara Fisher Ellison, Shane Greenstein, Scott Masten, and Andrea Shepard as well as those of participants at the NBER summer 1994 IO Institute, the Canadian Bureau of Competition workshop, the 1995 Econometrics Winter Meetings, the 1995 Society of Franchising Meetings, the MIT Industrial Organization Workshop, the 1995 Canadian Economics Association Meetings, and the UBC Summer Conference on Industrial Organization. I also thank Laura B. Phillips and Robert Picard for their wonderful assistance. The usual caveat applies. This paper is part of NBER's research program in Industrial Organization. Any opinions expressed are those of the author and not those of the National Bureau of Economic Research.

() 1995 by Francine Lafontaine. All rights reserved. Short sections of text, not to exceed two paragraphs, may be quoted without explicit permission provided that full credit, including $\odot$ notice, is given to the source. 


\title{
PRICING DECISIONS IN FRANCHISED CHAINS: A LOOK AT THE RESTAURANT \\ AND FAST-FOOD INDUSTRY
}

\begin{abstract}
This paper examines empirical issues of pricing and price dispersion within franchised restaurant and fast-food chains. Given the per se illegality of resale price maintenance (RPM) under current U.S. Antitrust laws, and the fact that franchised outlets are independent businesses under the law, franchisors must delegate the power to set prices to franchisees whereas corporate chains can control downstream prices directly. The issue I examine is whether it matters empirically who, between the franchisor or the franchisee, gets to choose downstream prices, and why.

After discussing a number of reasons why prices chosen by franchisees may differ from those that a franchisor would pick, I show, using data from all restaurant chains in the metropolitan Pittsburgh and Detroit areas, that there is price dispersion in fast-food franchising. I then show that the amount of price dispersion relates to the amount of franchising in a way that suggests that 1) franchisors are not able to control franchisees' prices indirectly to the same extent that they control company-owned unit prices and 2) the prices in franchised and corporate units are systematically different. Finally, I show that prices are systematically lower in corporate restaurants. This suggests that the reason behind the price differentials is not franchisor opportunism, but more likely double marginalization or, potentially, the existence of positive horizontal externalities among restaurants in a chain.
\end{abstract}

Francine Lafontaine

School of Business Administration

University of Michigan

Ann Arbor, MI 48109

and NBER 


\section{Introduction}

In the U.S., most of the research on franchising assumes that pricing decisions are made at the outlet level in a franchised chain (see e.g. Caves and Murphy (1976), Rubin (1978), Blair and Kaserman (1982), Barron and Umbeck (1984), Hadfield (1991), Gal'Or (1991), Gallini and Lutz (1992), Schmidt (1993), Shepard (1993), and Slade (1993)). This assumption is clearly appropriate given the per se illegality of resale price maintenance (RPM) under current U.S. Antitrust laws, and the fact that franchised outlets are considered independent businesses under the law. One issue that remains open at this point, however, is whether organizational structure affects final prices, or, put differently, whether it matters empirically, who, between the franchisor or the franchisee, gets to choose downstream prices, and why.

Smith II (1982), Barron and Umbeck (1984), Shepard (1993), Slade (1995a), and Graddy (1995) have examined empirically some aspects of this issue. ${ }^{1}$ The first was concerned with automobile distribution, the next two, with gasoline stations, and Slade (1995a), with beer retailing in the UK. Smith II (1982), Barron and Umbeck (1984) and Slade (1995a) all found that regulations imposing more restrictions on the kinds of contractual arrangements upstream firms could use with their dealers led to higher downstream prices. In particular, Barron and Umbeck (1984) found that the Maryland divorcement law, which prevented refiners from operating stations directly,

* University of Michigan Business School: This paper has benefitted from the comments of Frank Fisher, Sara Fisher Ellison, Shane Greenstein, Scott Masten, and Andrea Shepard as well as those of participants at the NBER summer $1994 \mathrm{I}-\mathrm{O}$ Institute, the Canadian Bureau of Competition workshop, the 1995 Econometrics Winter Meetings, the 1995 Society of Franchising Meetings, the MIT Industrial Organization Workshop, the 1995 Canadian Economics Association Meetings, and the UBC Summer Conference on Industrial Organization. I also thank Laura B. Phillips and Robert Picard for their wonderful assistance. The usual caveat applies.

1 Sass and Saurman (1993) also consider the empirical effect of territorial exclusivity on retail prices in the malt beverage industry. 
forcing them to franchise or sell their stations, led to higher downstream prices. ${ }^{2}$ Similarly, Slade (1995a) found that the mandated divestiture of public houses by brewers led to higher beer prices. However, all three of these studies focused on changes in regulatory regimes that were forcing upstream firms to change the way they did business with their retailers. Hence they were dealing with cases where the resulting contractual mix was by definition inefficient from the upstream firm's perspective. The higher downstream prices these authors found could, at least in part, be attributed to the inefficiency of the upstream firm's constrained retail system.

Shepard (1993) examined the effect of contractual form on prices in a context where refiners chose which station they wanted to operate under which type of contract. She found that downstream prices did not vary significantly across contractual forms except in the case of unleaded gasoline sold under full service, whose price was lower when it was under the refiners direct control than under contractual arrangements giving station operators the right to set prices. In other words, the differences in prices were large enough to be empirically observable only for the product whose demand was least elastic, that is the product for which the effect was expected to be the largest. She concluded that for the other gasoline products, refiners were probably able to control downstream prices indirectly, i.e., via forms of vertical restraints other than RPM.

All of the above studies focused on what the U.S. Department of Commerce calls "traditional" franchising, which is the type of franchising where the relationship is basically one of supplier-retailer under exclusive marks. Business format franchising, on the other hand, is defined as that part of franchising where the franchisor sells a turn-key operation to the franchisee, with operating manuals and ongoing assistance in running the business, in exchange typically for royalties on sales and an upfront franchise fee. Business format franchising includes, among other things, fast-food, business services, and personal services franchises. Graddy (1995), who examines the potential for price discrimination based on race or income by fast-food franchisors, is the only study that considers pricing in business format franchising. She includes,

2 Barron and Umbeck (1984) also examine the effect of changes in contractual arrangements on hours of operation. But while franchised gasoline retailers get to choose their hours of operation, franchisors in business format franchising typically specify these in their franchise contract. Ozanne and Hunt (1971), who examined individual clauses from 121 franchise contracts from the fast-food industry, found that franchisors set hours of operation contractually in $62 \%$ of these. 
among her explanatory variables, a company-owned dummy variable and finds that for her sample of four franchised chains, this variable has a negative effect on prices charged for food at individual restaurants. ${ }^{3}$

This paper complements the above literature because it examines systematically whether and why different contractual arrangements lead to differences in pricing decisions in franchised fast-food and restaurants chains within narrowly defined geographical areas, namely the Pittsburgh and Detroit metropolitan areas. Reasons to focus on this industry include the fact that the product offerings are very homogeneous within chains. Also, the downstream production function is standardized across all units within a chain. Hence costs, and especially marginal costs, should be relatively constant across units in a franchised chain, especially in narrowly defined geographical markets. As a result, observed price differences within such markets are unlikely to result from differences in costs or differences in product quality and the like. Instead, they will reflect demand variation or the effect of organizational form, namely of the corporate versus franchised decision. In addition, because of differences in the relationships themselves, and in the extent to which they are regulated, there might be differences in the extent to which business format franchisors, as opposed to traditional franchisors, can control downstream prices indirectly, or by means other than RPM. ${ }^{4}$ As most of the relatively scant literature has focused on traditional franchising, it is useful to determine whether their results hold in business format franchise relationships as well.

The paper is organized as follows. In the next section, various theories that could lead franchisees to want different prices from those preferred by franchisors are briefly reviewed, with an emphasis on the implications of these theories for the extent to which price dispersion would relate to the use or extent of franchising, and the relationship one would expect to find between the prices at company-owned and franchised outlets within chains. Section 3 contains a description of the data used in the empirical analyses. It also establishes the existence of price dispersion in fast-food franchises within the rather narrowly defined geographical markets under study. Section 4 presents the methodology and empirical results, beginning with an

3 Her analyses make use of the data collected by Card and Krueger (1994) for New Jersey and Pennsylvania.

4 In the remainder of this paper, franchising, franchisors, and franchisees denote business format franchising, business format franchisors, and business format franchisees. 
examination of the relationship between price dispersion and the extent to which a chain relies on franchising, followed by an analysis of the relationship between prices at corporate and franchised fast-food outlets. Section 5 summarizes and concludes.

\section{The Effect of Contractual Form on Prices: Theory and Implications}

\subsection{Why Might Franchisees Price Differently from Franchisors?}

Under perfect or Bertrand competition, one would not expect that the decision to franchise or operate a unit directly would have any effect on consumer prices. In fact, under these conditions, prices should be equated across all the units of any given chain operating within the same market by competitive forces, and so there should be no price dispersion within chains and no price differentials between corporate and franchised units. If, on the other hand, individual units possess some degree of market power, then price dispersion and price differentials might optimally arise from differences in the level of demand faced by different units. But under complete contracting, this type of price dispersion would occur regardless of the extent of franchising within the chain: Prices should not be systematically higher in franchised or corporate units unless these face systematically different market conditions.

Under incomplete contracting, however, existing theories suggest a number of reasons why franchisees in a franchised chain might want to price their products at a level that is different from the franchisor's preferred prices or from the prices franchisors use in their corporate stores. This section reviews each of these reasons, and discusses their implications for the relationship between price dispersion and the use of franchising, and the relationship between the prices in franchised and corporate units. A discussion of some mechanisms franchisors might use to control prices indirectly in franchised units, and thereby reduce the potential effect of contractual structure on price dispersion or price differentials under incomplete contracting, is also included in this section. The section concludes with a brief overview of a part of the literature that suggests that price delegation might be beneficial to franchisors, in which case franchisors would not want to indirectly (or directly) control downstream prices. 


\subsubsection{Double Marginalization or The Succession of Monopoly Problem}

The typical succession of monopoly problem arises from the fact that a monopolist upstream sells an input to a downstream firm at a price above marginal cost. If the downstream firm also has market power, it is well known that it will choose a price that is higher, and a quantity that is lower, than the price and quantity that would maximize joint profits. Barron and Umbeck (1984) and Shepard (1993) both discuss the potential effect of double marginalization on prices in traditional franchising.

In business format franchising however, and especially in the restaurant and fast food industry, the amount of inputs sold by franchisors to franchisees is generally quite small. Lafontaine (1992) shows that the value of inputs sold by franchisors in the restaurant and fast food industry averages only about $4.5 \%$ of franchisees' sales. ${ }^{5}$ Given the negative treatment of input sales requirements under antitrust in the U.S., much of the observed sales from franchisors to franchisees are likely to be voluntary, in which case franchisors must price competitively. ${ }^{6}$ In other words, even the low percentage of actual sales overestimates how much inputs are sold by franchisors to franchisees that are subject to some markup. In that sense the usual double marginalization argument does not apply to business format franchising as well as it does in traditional franchising (car dealership and gasoline stations) studied by Smith II (1982), Barron and Umbeck (1984) and Shepard (1993).

Despite the lack of input sales by franchisors in business format franchising, another form of "double marginalization" occurs because of the reliance on royalty rates. Royalty rates represent a tax on output that shifts the demand curve faced

${ }^{5}$ Lafontaine 's (1992) data shows that this percentage varies across sectors in business format franchising from a low of $1 \%$ in the auto rental industry to a high of about $30 \%$ in the non-food retailing and the automotive products and services sectors. The high proportions in non-food retailing and in the automotive product and services industry are probably explained by the fact that franchisees sell branded products provided by their franchisors. In all the other 12 sectors covered in her study, this percentage is below $10 \%$. Note that these percentages represent actual sales, not required sales.

6 The Chicken Delight decision (Siegel et.al. v. Chicken Delight, Inc, 448 F. 2d43 (9th Cir.1971)) was especially important in this respect. The usual interpretation of this decision has been that franchisors can only require franchisees to buy from them inputs that affect the quality and the uniformity of the consumer's experience. Even in this case, franchisors perceive that it is best if they can define their quality requirements, and allow franchisees to buy from approved suppliers. See Hunt and Nevin (1975), Klein and Saft (1985) and Lafontaine (1993) for more on the issue of input tying in business format franchising. 
by the franchisee downward. As a result, the franchisee maximizing his profits will choose a quantity that is below the quantity that the franchisor would prefer, and sell it at a price that, once adjusted to include the tax or the royalty on sales, will be above that which would have been optimal for the franchisor. Consequently, franchisors might try to control prices downward using various forms of vertical restraints discussed below. But given that franchisors get to choose their preferred prices in company-owned stores, if they are unsuccessful at controlling franchisees prices, double marginalization implies that everything else constant, prices in a company-owned store should be below those chosen by a franchisee. ${ }^{7}$ In turn, the fact that franchisors and franchisees would prefer different prices suggests that price dispersion should go up, then down again, as the proportion of franchised units in the chain goes from 0 to $100 \%$. In other words, when a chain is fully franchised or fully corporate, only the price dispersion due to varying demand levels will arise. But when it includes both franchised and company-owned units, price dispersion due to the differences in optimal prices between the two organizational forms will be added to the demand-induced price dispersion. ${ }^{8}$

\subsubsection{Positive Demand Externalities}

Barron and Umbeck (1984) also argue that demand externalities might lead franchisees to choose downstream prices above those that a vertically integrated firm would opt for. With positive demand externalities, lowering prices in one location

7 Shepard (1993) discusses how, under double marginalization, differences in price elasticities can affect the extent to which prices at franchised units can differ from prices in company-owned units. The more sensitive consumers are to prices, the more prices will tend to be equated across outlets by competitive forces. Note that while her discussion relates to price differentials due to double marginalization, her argument applies to any source of price differential: the extent of competition, and the price elasticity of demand, will reduce firms' capacity to charge different prices under all circumstances.

8 I thank Andrea Shepard for pointing out that the relationship would not be monotonic. For example, assume a linear demand curve at the outlet level, namely $p_{i}=a_{i}-b q_{i}$, where differences in market demand take the form of different intercepts that, for simplicity, I assume to be uniformly distributed on $[\underline{a}, \bar{a}]$. Then the optimal prices for the fully corporate chain would vary uniformly on $\left[\frac{a+c}{2}, \frac{\bar{a}+c}{2}\right]$. If the units were all franchised under a contract imposing a royalty rate of $r$, the optimal market prices (inclusive of the tax that is the royalty rate) would be uniformly distributed over $\left[\frac{a}{2}+\frac{c}{2(1-r)}, \frac{a}{2}+\frac{c}{2(1-r)}\right]$. Hence the actual range of prices would be the same whether the chain was fully franchised or fully corporate, but both limits are higher under franchising. The maximal price dispersion in this case would be achieved when the chain was $50 \%$ franchised. 
leads to an increase in quantity demanded at that location, but also increases demand at other locations. The franchisee maximizing his own profits will consider only the effect of his pricing decision on his own sales level. The franchisor, who benefits from the increased demand levels at other locations, would want the franchisee to choose a price that stimulates demand at other locations, that is a price below the one that maximizes the outlet's profits. Given that franchisors pick prices at companyowned outlets, and assuming that they are unsuccessful at controlling franchisees prices indirectly, this argument would also imply that everything else constant, prices at company-owned units should be below those at franchised outlets. And as above, with prices in corporate units systematically below prices in franchised units whatever the level of demand, price dispersion within a chain should go up, and then down, as the proportion of franchised units goes from 0 to $100 \%$.

On the other hand, negative demand externalities across outlets, or downstream competition, could lead franchisees to pick prices that are below the franchisor's optimal prices. Franchisors, however, can straightforwardly eliminate the effects of negative demand externalities and obtain their preferred price level from franchisees by correctly choosing their royalty rate. ${ }^{9}$ If they do, negative demand externalities would not lead to any systematic price differentials between company-owned and franchised units. However, if franchisors are constrained to pick a single royalty rate, the same for all franchisees, and market conditions vary across units in a chain, then the resulting prices at franchised and company-owned units may differently adjust to local market conditions. Still, on average, prices should be about the same under the two contract forms and price dispersion, if there is any, should be unrelated to the extent to which a chain is franchised.

\subsubsection{Franchisee Incentives and Effort Choices}

Shepard (1993) notes that franchisee moral hazard could lead them to choose effort levels so low that despite double marginalization or despite the externality problem, their prices might still be below those at company-owned units. ${ }^{10}$ While this could occur, the agency literature in general suggests that, other things equal, it

\footnotetext{
9 See Schmidt (1994) for a formal argument.

10 See Sass and Saurman (1993) for a dealer promotional service hypothesis to explain the use of vertical restraints in the malt beverage industry, and the higher prices that result from these restraints.
} 
is the manager of a corporate store that is more likely to put in too little effort. ${ }^{11}$ In that sense, the choice of effort by the company manager is likely to reinforce rather than weaken the effect of double marginalization or the effect of a positive externality problem. Thus, other things equal, agency-theoretic arguments might also lead to lower prices in company-owned units compared to franchised units. Still, the effort of company managers may be better monitored so that franchisors may successfully induce them to put in a lot of effort in those units that they operate corporately. As a result, without more information, it is difficult to predict the end effect of agency problems in terms of the relationship between prices in corporate and franchised units.

With respect to price dispersion however, franchise contract terms are not typically tailored to the characteristics of particular locations. Combined with less intense monitoring, this may give rise to more variation in franchisee effort levels than in company managers' effort. Under such conditions, assuming that prices respond to the various levels of franchisee effort, or more simply that prices are adjusted according to franchisee effort in franchised units but are unresponsive to managers' effort levels in company-owned restaurants - because the franchisor, not the manager, selects prices in those - then the amount of price dispersion one would find in a chain would increase with the amount of franchising that it does.

\subsubsection{Franchisor Opportunism}

As noted by Ozanne and Hunt (1971) and Hadfield (1990), franchisor opportunism may also give rise to differences in prices between company-owned and franchised units. ${ }^{12}$ Franchisors extract their revenues as a percentage of the sales rather than the profits of franchisees. As a result, ex-post, a franchisor might want its franchisees to maximize sales. Franchisees, on the other hand, are interested in maximizing profits. Hence franchisors might exert pressure on franchisees to reduce their prices and increase their sales volume. However, given that company-owned outlets are profit centers for the franchisors, they would not want to reduce prices in those. In other words, with franchisor ex-post opportunism, and assuming that franchisors

11 See Brickley and Dark (1987), Lafontaine (1992) and Shepard (1993) among others for empirical evidence that franchisors use franchising rather than company ownership to provide incentives to downstream operators.

12 See Ozanne and Hunt, (1971), p. 158, 159 for an early statement of this source of conflict between franchisors and franchisees. 
are to some extent successful in bringing franchisees' prices down, prices at companyowned outlets would be above prices in franchised units, contrary to what results from double marginalization or the positive externality effect. But because franchisor opportunism, like double marginalization or the positive externality argument, leads to systematically different prices in company-owned and franchised units, the amount of price dispersion would go up, then down, as the proportion of franchised units in the chain increases in this case as well. ${ }^{13}$

\subsubsection{Franchisors' Desire for Price Uniformity}

From a marketing perspective, franchisors might want a certain degree of price uniformity across units, at least within relatively narrowly defined market areas. Much of the concept and viability of franchising is built upon uniformity. Given that pricing is one aspect of the franchisor-consumer relationship, franchisors who strive for uniformity in the products and the experiences they offer to consumers might also want to offer the same prices to all customers. In fact, consumers may expect price uniformity, and react negatively toward a chain if they find "too much" price variation. In addition, price uniformity allows franchisors to include price information in their promotional materials. For example, franchisors might want price uniformity at the regional level so as to be able to include price information at least in their regional advertising.

If price uniformity is what franchisors are striving for, there need not be any systematic differences between prices in company-owned and franchised units, but one would expect more price dispersion the more franchised a chain is. That is unless franchisors successfully control prices in franchised units, in which case price

13 Another form of franchisor opportunism, studied in McAfee and Schwartz (1994), would lead franchisors to reduce their royalty rate and increase their franchise fee over time. This would mean that newer franchisees have a competitive advantage over older franchisees given that royalties on sales are a form of tax on output. As this tax is reduced for the newer franchisees, they can undercut the older franchisees and make higher profits that the franchisor then extracts via the higher upfront fee. Ultimately, this process would lead to the failure of the older franchisees. Knowing that franchisors have incentives to modify the terms of franchise contracts in this way, franchisees would refuse to enter into franchise relationships. Hence McAfee and Schwartz (1994) argue that franchisors must find some commitment mechanism that reassure franchisees. They note that one such mechanism may be the promise of relatively constant franchise contract terms. Because of data limitations, this form of franchisor opportunism is not considered here. 
dispersion would not occur. The next section considers various indirect mechanisms franchisors might use to control prices indirectly.

\subsection{The Use of Indirect Price Control Mechanisms}

Under all the arguments above, franchisors would prefer to control the prices in franchised units directly. Given the per se illegality of resale price maintenance, they might look for alternative mechanisms to control franchisees' prices.

A fairly extensive literature has shown how under perfect information, upstream firms with market power can use various forms and combinations of vertical restraints to obtain the "vertically integrated level of profits" from imperfectly competitive downstream markets. ${ }^{14}$ This literature implies that direct control over prices is unnecessary: Other forms of vertical restraints, such as franchise fees, exclusive territories, tying, and quantity forcing allow upstream firms to do as well as if they were able to control prices directly.

More specifically, in theory, the double marginalization problem can be eliminated by an upstream firm setting the wholesale price equal to marginal cost, and requiring the downstream firm to pay a fixed upfront fee equal to the present value of its profit stream. In the context of business format franchising, where the double marginalization problem arises due to the use of royalty rates, this solution would involve setting this rate to zero and increasing the franchise fee accordingly. Similarly, as noted by Barron and Umbeck (1984), the externality problem could be resolved by subsidizing franchisees' sales and extracting the resulting profits via a large upfront fee. Yet fixed fee only contracts are relatively rare, and sales subsidies are not observed in franchising. ${ }^{15}$ Either these solutions are not practical or appealing to franchisors, or the problems they are meant to correct are not really important in franchising.

Shepard (1993) discusses how refiners use quantity forcing and non-linear input

14 See especially Blair and Kaserman (1978) and (1980), Dixit (1983), Gallini and Winter (1983), Mathewson and Winter (1983) and (1984); the first two concentrate on monopolistic retailers, while the last four consider monopolistically competitive downstream markets.

15 Fixed fee contracts exist, but they are rare: Instead of requiring a percentage of sales as a royalty payment, some franchisors require their franchisees to pay a fixed monthly fee. In her sample of 548 franchisors, Lafontaine (1992) found that 37 had no royalty rates, and used ongoing fixed payments instead. 
prices to control the prices of their franchised dealers and eliminate double marginalization. She finds some evidence that refiners use these indirect methods to control prices at franchised locations. However, given that business format franchises do not involve much input sales by franchisors to franchisees, these mechanisms are not useful in fast-food franchising. Still, other indirect ways to control downstream prices are available in business format franchising. For one thing, using their advertising campaigns, which often provide price information and create consumer expectations about prices, franchisors may be able to maintain some degree of control over prices in their franchised outlets (see Caves and Murphy (1976)). Similarly, franchisors typically keep the right to choose the location of outlets in their chain. This power implies that they can affect the extent of downstream competition, and therefore indirectly exert pressure on franchisee's pricing decisions. ${ }^{16}$ Also, franchisors can use non-linear royalty schedules equivalent to refiners non-linear pricing schemes. ${ }^{17}$ Finally, franchisors can use sales targets or minimum royalty payments to affect downstream prices. And in fact a number of them do. ${ }^{18}$

As noted by Shepard (1993), if these mechanisms are as efficient at controlling prices as resale price maintenance is, we should find no systematic differences between the prices at company-owned and franchised stores (assuming that franchisors use these mechanisms in order to control downstream prices). In that case, there should be no relationship between price dispersion and the organizational structure of the chains either. Table 1 summarizes the implications of the arguments above in terms of the expected relationship between prices in corporate and franchised units, and the degree to which price dispersion should relate to franchising. This is done assuming first that franchisors cannot control prices indirectly, and then under the assumption that they can. This table thus provides a road map for the interpretation of empirical results below.

16 The issue of territorial encroachment, where franchisors are accused by franchisees of locating units too close to each other, has received a lot of attention in the courts, and has become the object of much debate at the federal and state level over the last few years. See for example "Franchise Update", 2nd quarter, 1994, for an account.

17 See Lafontaine (1992b) for evidence that some franchisors use non-linear royalty schedules (20 cases out of 118 respondents). Most franchisors (18 out of the 20) who used a non-linear scheme relied on a decreasing or sliding scale.

18 Lafontaine (1992b) found that 40 of the 123 respondents to her survey who required royalties from their franchisee imposed a minimum royalty payment. 
Table 1:

A Summary of Implications

\begin{tabular}{|c|c|c|}
\hline THEORY: & $\begin{array}{l}\text { Effect of Franchising on } \\
\text { Price Dispersion }\end{array}$ & $\begin{array}{l}\text { Relationship between } \\
P_{c} \text { and } P_{f}\end{array}$ \\
\hline $\begin{array}{l}\text { Perfect or Bertrand } \\
\text { Competition }\end{array}$ & None & $P_{c}=P_{f}$ \\
\hline \multicolumn{3}{|c|}{ Assuming Indirect Price Controls are Insufficient: } \\
\hline Double Marginalization & Up then down & $\mathrm{P}_{\mathrm{c}}<\mathrm{P}_{\mathrm{f}}$ \\
\hline Positive Externality & Up then down & $\mathrm{P}_{\mathrm{c}}<\mathrm{P}_{\mathrm{f}}$ \\
\hline Negative Externality & None & $P_{c}>P_{f}$ \\
\hline Incentive Issues & Positive & $\mathrm{P}_{\mathrm{c}} ? \mathrm{Pf}_{\mathrm{f}}$ \\
\hline $\begin{array}{l}\text { Franchisor Desire for } \\
\text { Uniformity }\end{array}$ & Positive & $P_{c}=P_{f}$ \\
\hline \multicolumn{3}{|c|}{ Assuming Indirect Price Controls are Sufficient: } \\
\hline All of the above become: & None & $P_{c}=P_{f}$ \\
\hline Franchisor Opportunism & Up then down & $P_{c}>P_{f}$ \\
\hline
\end{tabular}




\subsection{Can Franchisee-Induced Price Dispersion Benefit Franchisors?}

Most of the literature on franchising, and in particular all of the above arguments, consider price delegation to be costly to the franchisor (see for example Barron and Umbeck (1984), Gallini and Lutz (1992), Shepard (1993), and Slade (1993)). This literature sees the loss of price control that arises as a result of franchising as a major cost of franchising, and the illegality of resale price maintenance as a binding constraint on franchisors.

In theory, however, price dispersion in a franchised chain need not arise at the detriment of the franchisor. An upstream firm facing transactions costs might find it uneconomical to set prices optimally and individually for all locations in a chain. It might rely instead on single price policies, at least within regional markets. When it franchises units however, franchisees will choose prices optimally at each location. This could give rise to price dispersion that is beneficial to the franchisor. Empirically, this argument suggests that price dispersion should be positively related to the extent of franchising in a chain, but that on average, prices should be about the same in both types of units. Hence the implications of this transactions costs explanation would be the same as those obtained from the notion that franchisors want price uniformity. In that sense, the two are indistinguishable. However, Appendix A gives some evidence of pricing policies of fast-food chains for their corporate units. It shows that at least some chains choose to let prices vary across company-owned unit, a policy that contradicts both the notion that franchisors want uniform prices and the notion that it is too costly for them to tailor prices in company-owned units. On the other hand, other chains do use the same prices across all company-owned units, so the evidence on this issue remains inconclusive.

Similarly, price delegation can be optimal from the franchisor's perspective according to the vertical separation literature, where it allows oligopolistic franchisors or upstream firms to collude (e.g. Bonnano and Vickers (1988), Gal'Or (1991), and Slade (1993)), or to deter entry (Hadfield (1991)). In models of upstream collusion, the double marginalization mechanism allows franchisors to commit to higher prices than those that would arise under vertical integration. Franchisors would then extract the retailer's profits with a large upfront franchise fee. This literature does not have any direct implications as to the relationship between price dispersion and contractual structure as it implies that franchising is always the preferred organizational 
form (assuming the costs of delegation are the same across all units and are lower than the benefits derived from delegation). ${ }^{19}$ In fact, the main empirical implication of these models, aside from the direct implications of double marginalization noted above, is that franchisors should not attempt to control franchisees' prices directly or indirectly. Hadfield (1991), for example, notes how RPM would not be in the best interest of franchisors in her model.

According to the existing evidence, however, franchisors try to control franchisees' prices, which is not consistent with either of the "desirable price delegation" arguments. More specifically, franchisors put downward pressure on franchisees' prices. For example, in their survey of fast-food franchisors, Ozanne and Hunt (1971) found that "... complaints about the poor quality of pricing assistance center around franchisors trying to keep prices low." (p.158). They also found that $48 \%$ of franchisors believed they had almost complete responsibility to set retail prices, while another $24 \%$ believed they had much more responsibility for this than franchisees did. Note that franchisees did not feel the same way: $49 \%$ of them believed they (that is, the franchisees) had almost complete responsibility to set prices, and another $18 \%$ believed they had much more responsibility for this than their franchisors did ${ }^{20}$ Similarly, Love's (1986) account of Kroc's reaction to the decision of one of his franchisee to increase the price of its hamburgers from $\$ 0.15$ to $\$ 0.18$, shows how Kroc considered retail pricing decisions to be under his jurisdiction, and how keeping prices low was absolutely necessary in his mind to ensure the success of his enterprise. ${ }^{21}$ Also, the use of indirect price control mechanisms by fast-food franchisors, like including price information in advertising, requiring minimum royalty payments, using decreasing royalty schedules, etc. all suggest that franchisors are interested in affecting prices. The issue of territorial encroachment, namely franchisors' decisions to locate stores too close to each other according to franchisees, can be interpreted as an attempt by franchisors to put competitive pressure on franchisees' prices. Finally, Dnes (1992) presents some evidence that franchisors in the U.K., where the rules against RPM are significantly less stringent, especially for franchisors, in fact often set retail prices directly.

19 Also, the fact that the fast-food product market is rather differentiated is likely to make this type of upstream collusion rather difficult.

20 See Ozanne and Hunt (1971), pp. 153-154.

21 See Love (1986), p.75. 
As a whole, this evidence is generally inconsistent with arguments that fast-food franchisors find it beneficial to delegate pricing decisions to franchisees. ${ }^{22}$ For this reason, in the remainder of this paper, I focus mostly on those models and implications described in Table 1, where price delegation is assumed costly to franchisors.

\section{The Data}

To study the effect of contractual arrangements on outcomes such as prices, it is important that only the contract vary between the cases under study. This is rarely the case. Still, the data for this project were collected with the notion of keeping as many things as possible constant. In particular, the fact that most franchisors operate both franchised and company-owned restaurants allows for within chain comparisons that hold constant a number of unobservables.

The data used here were obtained mostly by telephone interviews. All the restaurants, donut shops and ice cream parlors of the major chains in the Metropolitan Pittsburgh and the Metropolitan Detroit areas, as identified in these cities' telephone directories, were contacted and asked for information about their prices and some other aspects of their operations. In Pittsburgh, this meant a total of 23 chains while in the Detroit area, the number was reduced to $13 .^{23}$ These surveys were conducted over a period of several months in the summer and fall of 1991. The survey also was repeated in the fall of 1993 for the Detroit metropolitan restaurants.

For restaurants, the survey questionnaire focused on the prices of 5 items for each chain, three "main courses", one drink and one side dish. In the case of donut shops and ice cream parlors, the survey asked for the prices of some of the main products, as well as one or two drinks (e.g. a soda and a coffee). Sizes were specified whenever appropriate. The goal was to keep the 5 items constant across all 3 surveys. Unfortunately, in part because of menu changes, this proved impossible in some cases,

22 However, see Slade (1993) for some evidence in favor of strategic vertical separation in the gasoline retailing industry. On the other hand, Slade (1995a) suggests that brewers lobbied against the imposition of restrictions on their "ownership" of pubs, and she finds that the profits of brewers declined when restrictions were imposed, and that despite the fact that prices went up. This evidence suggests that the restrictions on "ownership" were detrimental to brewers.

23 Several of the smaller or local chains in Pittsburgh did not have more than 1 or 2 restaurants in the Detroit area, so they were not surveyed in Detroit. No new chains were found to have enough units in Detroit to be added to the survey for that city. 
leading to a reduction in the number of items covered for some chains in some of the surveys. ${ }^{24}$ All prices quoted here are before taxes. In addition, respondents were asked to identify whether this was a franchised or a company-owned outlet, to indicate the number of years they had been operating at this location, and to note the "capacity" of the unit, measured by the number of seats. ${ }^{25}$ The years in operation and the capacity variables were meant to capture potential differences in per unit costs across outlets. Two copies of the questionnaire are included in Appendix B, one a generic version, the other a company specific version, for Arby's, which shows the items that were chosen for the restaurants in that chain. ${ }^{26}$

In order to control for differences in demand conditions across outlets, data on population, income and the ethnic composition of the population per zip code were obtained from The Sourcebook of ZIP Code Demographics. ${ }^{27}$ In addition, individual restaurants were classified as to whether or not they were located 1) on the highway, 2 ) in a mall, 3) in a business district, or 4) in an "inner" city area. ${ }^{28}$ Finally, to surmise the amount of competition in the market, data on the number of restaurants (SIC 5218: eating and drinking places) per zip code were obtained from the Census of Retail Trade. From the data, I was also able to determine, for each restaurant in the sample, the number of restaurants from the same chain in the same zip code.

24 In the case of Kentucky Fried Chicken, there was also a problem with one of the items chosen: the 3 piece Dinner. A number of restaurants offered instead a 3 piece snack, which priced about $\$ 1.00$ lower than the dinner. It was clear from the data that the prices we were quoted were sometimes for one of these, and sometimes for the other. Unfortunately, one could not always tell. As a result, in survey 3 , this item was replaced by a different one.

25 Unfortunately, the number of seats does not represent a good measure of capacity in the pizza industry, where many outlets do a significant amount of delivery. The appropriate measure here might have been the number of ovens or employees. Unfortunately, we were unable to get this type of information from respondents or from head offices.

26 A number of pieces of information were initially included in the survey, among which was the degree of participation of the restaurant in national promotions, and the existence of a drive-through window or not. However, the response rates on these, and a few other questions that do not even appear in the questionnaire in Appendix B, were so low that the survey was shortened early on in the process in an attempt to increase the response rate on those questions that were most crucial to the research project.

27 Variables that were also gathered from these sources but did not prove to have much effect on estimates, so were not used in the final analyses, were data on the age distribution and educational background of the population in each zip code.

28 The geographical areas for the latter two categories were defined by the author using various local sources and in consultation with some other individuals knowledgeable of the areas. 
As a way to prevent price variation within a chain from occurring due to differences in time frames, the restaurants for a given chain in a given city were always all called on the same day for prices ${ }^{29}$ Unfortunately, this almost completely ruled out the use of call-backs as a tool to increase response rates. As a result, the response rates were rather low for telephone interviews. ${ }^{30}$ Data on whether a restaurant was franchised or corporate proved especially difficult to obtain. Table 2 gives the relevant information on response rates. The total number $(\mathrm{N})$ of restaurants per chain in the Pittsburgh and Detroit area respectively at the time of each survey are found in the first column of the table. The next 2 columns indicate the number of company-owned $\left(n_{c}\right)$ and franchised $\left(n_{f}\right)$ restaurants respectively for which price and contract type data were obtained. The next 5 columns show the coefficient of variation $\left(\mathrm{CV}\left(p_{i}\right)\right)$ for the prices of each the 5 food items for which data were collected in each chain.

Table 2 clearly establishes the existence of price dispersion in fast-food franchising, even within narrowly defined geographical markets. And while in some chains the variation is quite small or even nil, in others, the standard deviation of individual prices is more than $10 \%$ of the average price. ${ }^{31}$ Having established that prices do vary in fast-food franchising, without which it would be very unlikely that the form of the contract under which a restaurant operates could affect observed prices, I now turn to a more thorough analysis to determine: 1) whether price dispersion relates to the use of franchising in a systematic way; and 2) whether prices at franchised units are typically above or below prices at company-owned units.

29 In several cases the survey was conducted in two parts, one part focusing on the prices only, and the other on the remainder of the information. This was done for two reasons. The first, related to the size of the chain, was the impossibility of covering a large number of outlets within a day with a limited number of interviewers if all questions were asked simultaneously. The second was that conducting the survey in two parts increased the likelihood that one could at least obtain the pricing information from reluctant respondents. Given that some of the needed information, notably the ownership status of a given location, the years in operation, and the capacity, was certainly available at the local head offices or at the national headquarters, efforts were made to contact people in these offices and request missing information directly from them. This approach typically did not produce much results.

30 Card and Krueger (1993) for example were able to achieve much higher response rates using call-backs.

31 Assuming a normal distribution for prices, a coefficient of variation of 0.10 would suggest that for every dollar spent on an item, about $70 \%$ of all observations would be between $\$ 0.90$ and $\$ 1.10$, while $95 \%$ of all observations would be within 2 standard deviations around the mean, that is between $\$ 0.80$ and $\$ 1.20$. 
TABLE 2:

Restaurants Sampled and Price Dispersion

\begin{tabular}{|lcccccccc|}
\hline \multicolumn{1}{|c}{ Chain } & Metropolitan Pittsburgh Area, Summer/Fall 1991 & & \\
\hline Arby's & $\mathrm{N}$ & $\mathrm{n}_{\mathbf{c}}$ & $\mathrm{n}_{\mathbf{f}}$ & $\mathrm{CV}\left(\mathrm{p}_{1}\right)$ & $\mathrm{CV}\left(\mathrm{p}_{2}\right)$ & $\mathrm{CV}(\mathrm{p} 3)$ & $\mathrm{CV}\left(\mathrm{p}_{4}\right)$ & $\mathrm{CV}(\mathrm{p} 5)$ \\
Baskin Robbins & 18 & 8 & 2 & 0.014 & 0.014 & 0.058 & 0.039 & 0.064 \\
Burger King & 17 & 0 & 15 & 0.058 & 0.075 & 0.054 & 0.075 & na \\
Chi Chi's & 27 & 0 & 21 & 0.033 & 0.052 & 0.055 & 0.099 & 0.049 \\
Dairy Queen (DQ) & 5 & 5 & 0 & 0.000 & 0.027 & 0.000 & 0.000 & 0.000 \\
DQ/Brazier & 13 & 2 & 5 & 0.092 & 0.071 & 0.082 & 0.089 & 0.079 \\
Denn's & 6 & 1 & 2 & 0.124 & 0.062 & 0.055 & 0.080 & 0.159 \\
Domino's Pizza & 6 & 5 & 0 & 0.016 & 0.004 & 0.001 & 0.001 & 0.000 \\
Dunkin Donuts & 24 & 0 & 15 & 0.058 & 0.054 & 0.037 & 0.037 & 0.064 \\
Eat N Park & 15 & 0 & 12 & 0.040 & 0.040 & 0.094 & 0.037 & 0.055 \\
Four Star Pizza & 17 & 17 & 0 & 0.000 & 0.000 & 0.000 & 0.000 & 0.000 \\
KFC & 6 & 0 & 6 & 0.066 & 0.070 & 0.037 & 0.036 & 0.123 \\
Little Caesar's & 25 & 17 & 1 & 0.035 & 0.021 & $\mathrm{na}$ & 0.073 & 0.000 \\
Long John Silver's & 15 & 11 & 3 & 0.000 & 0.000 & 0.013 & 0.000 & 0.008 \\
McDonald's & 16 & 12 & 0 & 0.012 & 0.000 & 0.000 & 0.000 & 0.036 \\
Mr. Donut & 34 & 12 & 9 & 0.045 & 0.046 & 0.053 & 0.027 & 0.055 \\
Pizza Hut & 14 & 0 & 5 & 0.000 & 0.000 & 0.000 & 0.000 & 0.000 \\
Ponderosa & 28 & 27 & 0 & 0.000 & 0.000 & 0.031 & 0.019 & 0.030 \\
Rax & 9 & 8 & 0 & 0.000 & 0.000 & 0.000 & 0.000 & 0.000 \\
Roy Rogers & 13 & 5 & 6 & 0.026 & 0.027 & 0.009 & 0.027 & 0.019 \\
Subway & 11 & 10 & 0 & 0.000 & 0.000 & 0.000 & 0.000 & 0.000 \\
Taco Bell & 33 & 0 & 23 & 0.038 & 0.066 & 0.030 & 0.047 & 0.095 \\
Wendy's & 3 & 3 & 0 & 0.000 & 0.000 & 0.000 & 0.000 & 0.000 \\
\hline & 26 & 0 & 19 & 0.000 & 0.000 & 0.044 & 0.033 & 0.014 \\
\hline
\end{tabular}

Note: $N$ represents the total number of restaurants in the chain in the metropolitan area, $n_{c}$ and $n_{f}$, the number of company-owned and franchised restaurants respectively that we could identify as such and obtain price data from, and $C V\left(p_{i}\right), I=1, \ldots, 5$, are the coefficients of variation of the prices for each of the five items. 
TABLE 2: (cont'd)

\begin{tabular}{|lcccccccc|}
\hline \multicolumn{1}{|c|}{ Chain } & $\mathrm{N}$ & $\mathrm{n}_{\mathrm{c}}$ & $\mathrm{n}_{\mathbf{f}}$ & $\mathrm{CV}(\mathrm{p} 1)$ & $\mathrm{CV}(\mathrm{p} 2)$ & $\mathrm{CV}(\mathrm{p} 3)$ & $\mathrm{CV}(\mathrm{p} 4)$ & $\mathrm{CV}(\mathrm{p} 5)$ \\
\hline Arby's & 8 & 3 & 1 & 0.054 & 0.012 & 0.030 & 0.086 & 0.019 \\
Baskin Robbins & 18 & 1 & 12 & 0.056 & 0.119 & 0.111 & 0.069 & 0.045 \\
Burger King & 30 & 5 & 6 & 0.014 & 0.032 & 0.099 & 0.039 & 0.066 \\
Domino's Pizza & 26 & 1 & 12 & 0.040 & 0.035 & 0.055 & 0.043 & 0.099 \\
Dunkin Donuts & 6 & 0 & 5 & 0.025 & 0.024 & 0.023 & 0.040 & 0.039 \\
KFC & 39 & 20 & 1 & 0.003 & 0.065 & na & 0.098 & 0.019 \\
Little Caesar's & 44 & 20 & 4 & 0.017 & 0.015 & 0.041 & 0.171 & 0.157 \\
Long John Silver's & 5 & 5 & 0 & 0.000 & 0.000 & 0.000 & 0.028 & 0.056 \\
McDonald's & 51 & 7 & 16 & 0.044 & 0.045 & 0.048 & 0.054 & 0.101 \\
Pizza Hut & 15 & 9 & 1 & 0.000 & 0.013 & 0.000 & 0.019 & 0.000 \\
Ponderosa & 6 & 3 & 0 & 0.000 & 0.046 & 0.000 & 0.069 & 0.006 \\
Subway & 7 & 0 & 3 & 0.105 & 0.000 & 0.125 & 0.056 & 0.000 \\
Wendy's & 24 & 5 & 8 & 0.026 & 0.031 & 0.050 & 0.062 & 0.049 \\
\hline
\end{tabular}

\begin{tabular}{|lcccccccc|}
\hline \multicolumn{1}{|c}{ Chain } & $\mathrm{N}$ & $\mathrm{n}_{\mathrm{c}}$ & $\mathrm{n}_{\mathbf{f}}$ & $\mathrm{CV}(\mathrm{p} 1)$ & $\mathrm{CV}(\mathrm{p} 2)$ & $\mathrm{CV}(\mathrm{p} 3)$ & $\mathrm{CV}(\mathrm{p} 4)$ & $\mathrm{CV}(\mathrm{p} 5)$ \\
\hline Arby's & 8 & 1 & 4 & 0.032 & 0.026 & na & 0.070 & 0.048 \\
Baskin Robbins & 15 & 1 & 11 & 0.078 & $\mathrm{na}$ & 0.091 & $\mathrm{na}$ & 0.081 \\
Burger King & 26 & 4 & 10 & 0.091 & 0.067 & 0.085 & $\mathrm{na}$ & 0.152 \\
Domino's Pizza & 24 & 0 & 11 & 0.000 & 0.002 & 0.000 & 0.000 & 0.017 \\
Dunkin Donuts & 8 & 0 & 8 & 0.029 & $\mathrm{na}$ & 0.052 & $\mathrm{na}$ & 0.058 \\
KFC & 38 & 28 & 6 & 0.039 & $\mathrm{na}$ & 0.024 & $\mathrm{na}$ & 0.038 \\
Little Caesar's & 33 & 17 & 5 & 0.104 & 0.156 & 0.063 & 0.236 & 0.129 \\
Long John Silver's & 4 & 3 & 0 & 0.015 & 0.000 & $\mathrm{na}$ & 0.095 & 0.000 \\
McDonald's & 45 & 10 & 26 & 0.043 & 0.058 & 0.040 & 0.100 & 0.096 \\
Pizza Hut & 15 & 11 & 3 & 0.000 & 0.000 & 0.000 & 0.000 & 0.042 \\
Ponderosa & 6 & 1 & 2 & 0.060 & 0.099 & 0.110 & 0.000 & 0.056 \\
Subway & 11 & 0 & 10 & 0.080 & 0.117 & 0.121 & $\mathrm{na}$ & 0.059 \\
Wendy's & 18 & 5 & 7 & 0.023 & 0.036 & 0.018 & 0.014 & 0.032 \\
\hline
\end{tabular}

Note: $\mathrm{N}$ represents the total number of restaurants in the chain in the metropolitan area, $\mathrm{n}_{\mathrm{c}}$ and $\mathrm{n}_{\mathrm{f}}$, the number of company-owned and franchised restaurants respectively that we could identify as such and obtain price data from, and $C V\left(p_{i}\right), I=1, \ldots, 5$, are the coefficients of variation of the prices for each of the five items. 


\section{Methodology and Results}

\subsection{Price Dispersion and Franchising}

If franchising first and foremost gives rise to more price variation than franchisors would want, either because of incentive problems or because franchisors prefer price uniformity, one should find that the price dispersion in Table 2 mostly arises within the set of franchised units. ${ }^{32}$ On the other hand, if the price dispersion in Table 2 is due to the fact that franchisees and franchisors choose systematically different prices - as they would under double marginalization, the externality arguments or franchisor opportunism - the price dispersion in Table 2 would come from both corporate and franchised units assuming that both adjust their prices to local demand conditions.

Table 3 gives the details of the amount of price dispersion among the companyowned and the franchised units separately for each chain in each survey for which I have enough data to do these calculations, namely data for two or more franchised and company-owned restaurants. The first line of data for each chain gives the coefficient of variation of prices of company-owned restaurants, the second line, the coefficient of variation of prices in franchised units, and the third gives the results from testing the equality of the variances of these two population of units. As this table shows, and consistent with the data summarized in Appendix A, price dispersion occurs among corporate units just as it does among the franchised units of the same chain. ${ }^{33}$ In fact, for the great majority of cases where the test could be performed, the variances of prices in the two types of outlets are not statistically different. In those cases where they are, it is more often the variance of prices in franchised units that is greater than the variance in corporate units. However, there are also a few items for which the variance in prices is significantly greater among the corporate units.

32 There are clearly cases in Table 2 where price dispersion is positive and there are no franchised units in the sample. This implies that the strong form of this hypothesis - the notion that all price dispersion is due to franchising - can be dismissed already.

33 There is one case, Arby's, where the corporate office said that prices were the same nationally, yet the data showed variation in the prices across corporate units. In a few other cases, the corporate office said that prices did not vary within regions, yet the data again showed some amount of variation within metropolitan areas. This could be explained by different notions of regions, such as, for example, a definition based on suburban vs. urban within a metropolitan area. 


\section{Table 3}

First line: Coefficient of Variation of Prices for Company-Owned Units

Second line: Coefficient of Variation of Prices for Franchised Units

Third line: Tests for Equality of Variances Between Company-Owned and Franchised Units

\begin{tabular}{|c|c|c|c|c|c|c|}
\hline \multicolumn{7}{|c|}{ Metropolitan Pittsburgh Area: Summer/Fall 1991} \\
\hline Chain & $\mathbf{n}$ & p1 & p2 & p3 & p4 & p5 \\
\hline \multirow[t]{3}{*}{ Arby's } & 8 & 0.013 & 0.015 & 0.062 & 0.034 & 0.037 \\
\hline & 2 & 0.017 & 0.000 & na & 0.068 & 0.143 \\
\hline & & equal & na & na & equal & not equal \\
\hline \multirow[t]{3}{*}{ Dairy Queen } & 2 & 0.094 & 0.106 & 0.111 & 0.015 & 0.043 \\
\hline & 5 & 0.102 & 0.069 & 0.074 & 0.103 & 0.092 \\
\hline & & equal & equal & equal & equal & equal \\
\hline \multirow{3}{*}{ Little Caesar's } & 11 & 0.000 & 0.000 & 0.000 & 0.000 & 0.007 \\
\hline & 3 & 0.000 & 0.000 & 0.027 & 0.000 & 0.000 \\
\hline & & equal & equal & na & equal & na \\
\hline \multirow[t]{3}{*}{ McDonald's } & 12 & 0.026 & 0.023 & 0.028 & 0.028 & 0.045 \\
\hline & 9 & 0.055 & 0.055 & 0.059 & 0.027 & 0.066 \\
\hline & & not equal & not equal & not equal & equal & equal \\
\hline \multirow[t]{3}{*}{$\operatorname{Rax}$} & 5 & 0.035 & 0.033 & 0.000 & 0.000 & 0.026 \\
\hline & 6 & 0.019 & 0.015 & 0.007 & 0.037 & 0.000 \\
\hline & & equal & equal & na & na & na \\
\hline
\end{tabular}

\begin{tabular}{|c|c|c|c|c|c|c|}
\hline \multicolumn{7}{|c|}{ Metropolitan Detroit Area: Fall 1991} \\
\hline Chain & $\mathbf{n}$ & $\mathrm{p}_{1}$ & $\mathrm{p}_{2}$ & p3 & $\mathrm{p}_{4}$ & p5 \\
\hline \multirow[t]{3}{*}{ Burger King } & 5 & 0.020 & 0.038 & 0.038 & 0.037 & 0.093 \\
\hline & 6 & 0.000 & 0.024 & 0.129 & 0.040 & 0.029 \\
\hline & & na & equal & not equal & equal & not equal \\
\hline \multirow[t]{3}{*}{ Little Caesar's } & 20 & 0.000 & 0.001 & 0.033 & 0.186 & 0.154 \\
\hline & 4 & 0.043 & 0.037 & 0.074 & 0.078 & 0.196 \\
\hline & & na & not equal & not equal & equal & equal \\
\hline \multirow[t]{3}{*}{ McDonald's } & 7 & 0.023 & 0.066 & 0.049 & 0.023 & 0.021 \\
\hline & 16 & 0.047 & 0.026 & 0.027 & 0.050 & 0.095 \\
\hline & & equal & not equal & equal & equal & not equal \\
\hline \multirow[t]{3}{*}{ Wendy's } & 5 & 0.022 & 0.034 & 0.047 & 0.038 & 0.058 \\
\hline & 8 & 0.028 & 0.031 & 0.055 & 0.059 & 0.046 \\
\hline & & equal & equal & equal & equal & equal \\
\hline
\end{tabular}




\section{Table 3 (cont'd)}

First line: Coefficient of Variation of Prices for Company-Owned Units

Second line: Coefficient of Variation of Prices for Franchised Units

Third line: Tests for Equality of Variances Between Company-Owned and Franchised Units

\begin{tabular}{|c|c|c|c|c|c|c|}
\hline \multirow[b]{2}{*}{ Chain } & \multicolumn{4}{|c|}{ Metropolitan Detroit Area: Fall 1993} & \multirow[b]{2}{*}{ p4 } & \multirow[b]{2}{*}{ p5 } \\
\hline & $\mathbf{n}$ & $\mathrm{p}_{1}$ & $\mathrm{p}_{2}$ & $\mathrm{p}_{3}$ & & \\
\hline Burger King & $\begin{array}{c}4 \\
10\end{array}$ & $\begin{array}{c}0.020 \\
0.103 \\
\text { not equal }\end{array}$ & $\begin{array}{l}0.069 \\
0.069 \\
\text { equal }\end{array}$ & $\begin{array}{l}0.119 \\
0.062 \\
\text { equal }\end{array}$ & $\begin{array}{l}\text { na } \\
\text { na } \\
\text { na }\end{array}$ & $\begin{array}{l}0.099 \\
0.176 \\
\text { equal }\end{array}$ \\
\hline $\mathrm{KFC}$ & $\begin{array}{c}28 \\
6\end{array}$ & $\begin{array}{c}0.019 \\
0.088 \\
\text { not equal }\end{array}$ & $\begin{array}{l}\text { na } \\
\text { na } \\
\text { na }\end{array}$ & $\begin{array}{c}0.023 \\
0.032 \\
\text { not equal }\end{array}$ & $\begin{array}{l}\text { na } \\
\text { na } \\
\text { na }\end{array}$ & $\begin{array}{c}0.027 \\
0.052 \\
\text { not equal }\end{array}$ \\
\hline Little Caesar's & $\begin{array}{c}17 \\
5\end{array}$ & $\begin{array}{l}0.096 \\
0.138 \\
\text { equal }\end{array}$ & $\begin{array}{l}0.156 \\
0.174 \\
\text { equal }\end{array}$ & $\begin{array}{l}0.065 \\
0.066 \\
\text { equal }\end{array}$ & $\begin{array}{l}0.234 \\
0.264 \\
\text { equal }\end{array}$ & $\begin{array}{c}0.144 \\
0.000 \\
\text { na }\end{array}$ \\
\hline McDonald's & $\begin{array}{l}10 \\
26\end{array}$ & $\begin{array}{l}0.034 \\
0.047 \\
\text { equal }\end{array}$ & $\begin{array}{l}0.062 \\
0.057 \\
\text { equal }\end{array}$ & $\begin{array}{l}0.037 \\
0.040 \\
\text { equal }\end{array}$ & $\begin{array}{c}0.133 \\
0.075 \\
\text { not equal }\end{array}$ & $\begin{array}{l}0.069 \\
0.102 \\
\text { equal }\end{array}$ \\
\hline Pizza Hut & $\begin{array}{c}11 \\
3\end{array}$ & $\begin{array}{l}0.000 \\
0.000 \\
\text { equal }\end{array}$ & $\begin{array}{l}0.000 \\
0.000 \\
\text { equal }\end{array}$ & $\begin{array}{l}0.000 \\
0.000 \\
\text { equal }\end{array}$ & $\begin{array}{l}0.000 \\
0.000 \\
\text { equal }\end{array}$ & $\begin{array}{l}0.040 \\
0.056 \\
\text { equal }\end{array}$ \\
\hline Wendy's & $\begin{array}{l}5 \\
7\end{array}$ & $\begin{array}{l}0.014 \\
0.022 \\
\text { equal }\end{array}$ & $\begin{array}{l}0.029 \\
0.031 \\
\text { equal }\end{array}$ & $\begin{array}{l}0.014 \\
0.021 \\
\text { equal }\end{array}$ & $\begin{array}{l}0.018 \\
0.009 \\
\text { equal }\end{array}$ & $\begin{array}{l}0.032 \\
0.034 \\
\text { equal }\end{array}$ \\
\hline
\end{tabular}


The relationship between the extent of franchising and price dispersion can be examined further by using the data from all surveyed chains - instead of only those with two or more of each type of units - and estimating the following reduced-form equation:

$$
\begin{gathered}
C V_{i j k}\left(P_{i h j k}\right)=\beta_{0}+\beta_{1} \% \text { Franch }_{j k}+\beta_{2} \% \text { Franch }_{j k}^{2}+\beta_{3} \text { Mean } P_{i j k}+ \\
+\beta_{5} \text { Detroit } 91+\beta_{6} \text { Detroit } 93+\sum_{r=1}^{R} \alpha_{r} Z_{r j k}+\epsilon_{i j k}
\end{gathered}
$$

where $P_{i h j k}$ represents the price of item i, $i=1 \ldots 5$, in restaurant $\mathrm{h}, h=1, \ldots, n_{j k}$, and $n_{j k}=n_{j k}^{c}+n_{j k}^{f}$, in chain $\mathrm{j}, j=1 \ldots 23$, in survey $\mathrm{k}$, where $k=1$ for Pittsburgh, $k=2$ for the 1991 Detroit survey, and $k=3$ for the 1993 Detroit survey. In other words, the coefficient of variation is calculated, as in Table 2, across all $n_{j k}$ restaurants in the chain, corporate or franchised, that provided data in that survey. The $\%$ Franch $_{j k}$ is measured as the proportion of franchised units among the chain's sampled restaurants. The model includes a quadratic term for the proportion of franchised units to allow for the type of relationship - an inverted $U$ - suggested by some of the theories. ${ }^{34}$

The above model includes the mean price of the item across the restaurants in the same chain in the same survey, $M e a n P_{i j k}$, among the regressors because there is some evidence that average price levels relate positively to price dispersion (Pratt, Wise and Zeckhauser (1979) and Borenstein and Rose (1991)). The presence of this regressor also controls for systematic differences in the potential pricing policies of these restaurants with respect to more or less pricy items. The $Z_{r j k}$ 's are chain characteristics that may affect the degree of price dispersion. The main such variable is the royalty rate, which under the double marginalization argument, should increase the prices demanded at franchised units, thereby increasing the degree of price dispersion for a given mix of company-owned and franchised units in the chain. However, the effect of the royalty rate should be small in either mostly corporate or mostly franchised chains. This suggests that the model should include some interaction term

34 Other functional forms, including linear ones with breakpoints and reversals at different levels of franchising, or ones with dummy variables for fully franchised and fully corporate chains were used also to capture the effect of the extent of franchising on price dispersion. They gave equivalent qualitative results as the quadratic. For that reason only results based on this simple functional form are reported below. 
between the royalty rate and the proportion of franchised restaurants such that the maximal effect of the royalty rate on price dispersion can occur when the chain uses a mix of types of units. ${ }^{35}$ However, the introduction of these interactive terms led to multicollinearity problems and, more importantly, did not fundamentally change any result. At the same time, they made the interpretation of coefficients of interest, namely the coefficient on the proportion of franchised restaurants and its square, more complicated. ${ }^{36}$ For that reason, the results reported below are based on the simpler specification above, with no interaction terms. Finally, other chain characteristics, such as the number of years of experience of the franchisor and the total number of units in the chain, both of which may affect the cost of a franchisor's pricing policies and hence the extent to which the franchisor will try to control downstream prices, are included in the model. All the franchisor or chain level data were obtained from Entrepreneur's "Franchise 500 Survey." (See Tables A and B in Appendix C for the chain level data.)

The dependent variable in equation (4.1) is censored at 0 since price dispersion cannot be negative. As a result, the maximum likelihood tobit estimator is used in all regressions. In other words, the estimated model is really given by equation (4.1) if the right hand side of it is greater than 0 , and $C V_{i j k}\left(P_{i h j k}\right)=0$ otherwise. Table 4 gives descriptive statistics for all the relevant variables. Regression results under various specifications of equation (4.1) are found in Table 5.

35 I thank Frank Fisher for bringing up this issue.

36 For example, the inclusion in the regression described in Column 4 of Table 5 of a simple cross term between the royalty rate and the proportion franchised gives the following results: $\beta_{1}=0.195, \beta_{2}=-0.089$, a coefficient for royalty rate at 0.007 , and for the interaction term, -0.008 , all significant at the $5 \%$ level. These results suggest that the royalty rate does have an important positive effect on price dispersion, but that this effect is reduced as the proportion of franchised units goes up. At the average \%franchised of 0.5 , the derivative of the estimated equation with respect to the royalty rate is $0.007-0.5 \cdot 0.008=0.003$, as in Table 5. However, the results also, at first glance, suggest that the amount of price dispersion is maximized in the data at a proportion of franchised units that is above 1 (more specifically, $1.95 /(2 \cdot 0.089)=1.096)$. This interpretation is incorrect: it ignores the effect of the interaction term. At the average royalty rate of 8.25 for example, the derivative of the estimated equation with respect to the proportion of franchised units is $0.195-0.008 \cdot 8.25-2 \cdot 0.089 \cdot \%$ franchised, which is maximized when the proportion franchised is 0.7 , quite close to what is implied by results in table 5. Regressions performed with the above interactive term and an interaction between royalty rates and the square of the proportion franchised gave equivalent results except that they did give a pattern where the effect of an increase in the royalty rate first increases and then decreases as the proportion of franchising increases. 
Table 4

Descriptive Statistics on the Price Dispersion Data

\begin{tabular}{|l|ccccc|}
\hline & $\begin{array}{c}\text { Nb. of } \\
\text { Obs. }\end{array}$ & Mean & $\begin{array}{c}\text { Std. } \\
\text { Deviation }\end{array}$ & Minimum & Maximum \\
\hline Coef. Variation & 232 & 0.041 & 0.041 & 0.000 & 0.236 \\
\% franchised $\left(\mathrm{n}_{\mathrm{f}} /\left(\mathrm{n} \mathrm{f}+\mathrm{n}_{\mathrm{c}}\right)\right)$ & 232 & 0.51 & 0.41 & 0.00 & 1.00 \\
Squared \%franchised & 232 & 0.42 & 0.42 & 0.00 & 1.00 \\
Sampled \# of units & 232 & 12.50 & 7.85 & 3.00 & 36.0 \\
\# of franchised units & 232 & 6.42 & 6.70 & 0.00 & 26.0 \\
\# co-owned units & 232 & 6.09 & 6.95 & 0.00 & 28.0 \\
Mean price (in cents) & 232 & 3.23 & 3.09 & 0.19 & 16.9 \\
Royalty rate (r) (in \%) & 192 & 8.25 & 2.12 & 3.50 & 12.000 \\
Worlwide units & 192 & 4245 & 3057 & 84 & 13230 \\
Franchisor's age & 192 & 28.84 & 10.21 & 6.00 & 47.00 \\
Detroit 91 Dummy & 232 & 0.276 & 0.448 & 0.00 & 1.00 \\
Detroit 93 Dummy & 232 & 0.237 & 0.426 & 0.00 & 1.00 \\
\hline
\end{tabular}


Table 5

TOBIT Results on Price Dispersion

\begin{tabular}{|l|cccc|}
\hline & \multicolumn{4}{|c|}{ Dependent var $=$ Coef. varijk $\left(\mathrm{P}_{\text {ihjk }}\right)$} \\
\cline { 2 - 5 } Independent variables: & 1 & 2 & $3(1)$ & $4(1)$ \\
\hline \% franchised & $0.215^{* *}$ & $0.202^{* *}$ & $0.155^{* *}$ & $0.128^{* *}$ \\
Squared \%franchised & $(6.09)$ & $(5.71)$ & $(4.31)$ & $(3.39)$ \\
$\quad=\left(\mathrm{n}_{\mathrm{f}} /\left(\mathrm{n}_{\mathrm{f}}+\mathrm{n}_{\mathrm{C}}\right)\right)^{2}$ & $-0.162^{* *}$ & $-0.151^{* *}$ & $-0.117^{* *}$ & $-0.093^{* *}$ \\
Mean price (in cents) & $(-4.87)$ & $(-4.55)$ & $(-3.56)$ & $(-2.73)$ \\
& & $-0.002^{*}$ & $-0.003^{*}$ & $-0.002^{*}$ \\
Royalty Rate & & $(-1.96)$ & $(-2.41)$ & $(-2.04)$ \\
& & & 0.002 & $0.003^{+}$ \\
Worlwide units in the & & & $(1.45)$ & $(1.71)$ \\
chain (in 1000's) & & & -0.000 \\
Franchisor's years of & & & & $-0.001)$ \\
experience & & & & $0.001^{* *}$ \\
Detroit 91 Dummy & $0.015^{*}$ & $0.016^{*}$ & 0.009 & $(2.81)$ \\
& $(2.03)$ & $(2.15)$ & $(1.20)$ & 0.007 \\
Detroit 93 Dummy & $0.015^{+}$ & $0.017^{*}$ & $0.014^{+}$ & $(1.02)$ \\
& $(1.88)$ & $(2.14)$ & $(1.84)$ & 0.012 \\
Constant & $-0.017^{*}$ & -0.009 & -0.005 & $-0.031^{+}$ \\
& $(-2.54)$ & $(-1.18)$ & $(-0.31)$ & $(-1.80)$ \\
\hline No. of Limit Obs. & 61 & 61 & 28 & 28 \\
No. of Non-limit Obs. & 171 & 171 & 164 & 164 \\
Sq. Cor. (Y, E(Y)) & 0.21 & 0.22 & 0.16 & 0.21 \\
LR test (all betas $=0)$ & $77.26^{* *}$ & $81.12^{* *}$ & $44.23^{* *}$ & $53.21^{* *}$ \\
\hline
\end{tabular}

Asymptotic 2-tail t-statistics in parentheses: ${ }^{* *}=$ Sign. at $0.01, *=$ Sign. at $0.05,+=$ Sign. at 0.10 .

(1) The subsample in this regression excludes all corporate chains due to the need for royalty rate and other franchising specific data. 
Results show most importantly that the relationship between price dispersion and the use of franchising does follow an inverted " $U$ ". At the same time, they show that the level of price dispersion for fully corporate chains (when $\%$ franchised is equal to 0 ) is significantly below the level of price dispersion of fully franchised chains. ${ }^{37}$

These results suggest that a combination of effects explains price dispersion in franchised firms. In particular, it appears that franchisors do limit price dispersion in corporate stores more than they do in franchised units. This could be due to incentive effects or to a greater desire for uniformity on the part of the franchisor. However, some of the price dispersion in Table 2 must also be due to a systematic difference between optimal prices for franchised and company-owned units, as with double marginalization or positive externality or franchisor opportunism, otherwise one would not find that price dispersion first increases, then decreases with the amount of franchising. In the next section, I take a closer look at price differentials to try to disentangle some of these effects.

Before turning to that however, it is worth noting from Table 5 that price dispersion is systematically greater in the Detroit area than in Pittsburgh. Why this is so remains unclear at this point. A study based on more markets might shed some light on this issue. Also, the regression results indicate that the number of units in the chain has no effect on price dispersion, but the number of years since the franchisor began franchising has a positive effect on price dispersion. This may occur because the more experienced franchisor is better at reacting to local conditions. The results relative to the royalty rate are generally consistent with the double marginalization argument: The royalty rate affects price dispersion positively, though the statistical significance of the estimate is weak. Finally, the mean price has a negative effect on the amount of price dispersion in these data. ${ }^{38}$ In the context of franchising, this result seems quite sensible: If franchisors advertise prices of meals or other "costly" items more often, consumers are more likely to have specific expectations about these

37 In other words, the sum of the coefficient on the proportion franchised and its square is statistically greater than 0 in all regressions in Table 5 . Because of this asymmetry, the coefficients show that the maximum level of price dispersion is found when the chain is about $2 / 3$ franchised. This is largely due to the use of a quadratic functional form. However, the same general pattern of inverted " $U$ " and lower intercept at 0 than at 1 were found with alternative specifications of the relationship between price dispersion and the extent of franchising.

See e.g. Borenstein and Rose (1991) for a case where the observed relation between price dispersion (measured either by the GINI coefficient or the coefficient of variation) and mean price is positive. 
prices compared to those for drinks or fries. This in turn makes it easier for franchisees and corporate store managers to charge different prices for low price as opposed to main meal items.

\subsection{Prices in Company-Owned and Franchised Units}

The second empirical issue I address is the relationship between prices in company-owned and franchised units. Table 6 gives the ratio of average prices for each item for each chain in each survey where there were at least 1 franchised and 1 corporate restaurant that provided pricing data. As can be seen from this table, it is not clear whether prices are higher in corporate or in franchised units. In all surveys, there are an equivalent number of cases where the corporate prices are above and below the franchised prices. Also, within chains, there does not appear to be a systematic pattern across all items in terms of which type of outlet prices higher.

\subsubsection{OLS Results}

To examine this relationship further, the effect of contract choice on prices is estimated in an equation that relates the difference between an individual price and the mean price - across all restaurants in that chain in the same survey - to the organizational form. The equation also includes controls for market characteristics and outlet characteristics as well as chain and survey dummy variables. More precisely, the estimated equation is:

$$
\begin{aligned}
\frac{P_{i j h k}-\text { Mean } P_{i j k}}{\text { MeanP } P_{i j k}}=\beta_{0}+ & \beta_{1} \operatorname{Corp}_{j h k}+\beta_{2} \text { Detroit } 91+\beta_{3} \text { Detroit } 93 \\
& +\sum_{j=1}^{12} \alpha_{j} D_{j}+\sum_{s=1}^{S} \gamma_{s} X_{s j h k}
\end{aligned}
$$

where, as above, $P_{i j h k}$ represents the price of item $i$ in restaurant $h$ in chain $j$ in survey $k$, and $M e a n P_{i j k}$ is the mean price of the item across the restaurants in the same chain in the same survey, and Detroit 91 and Detroit 93 are survey-specific dummy variables. Corp $p_{j h k}$ is a dummy variable set equal to 1 if the restaurant is companyowned, and 0 otherwise. The $D_{j}$ 's are a set of 12 chain-specific dummy variables, as 
TABLE 6:

Ratios of Average Prices: Company-Owned/Franchised

1. Metropolitan Pittsburgh Area: Summer/Fall 1991

\begin{tabular}{|l|ccccc|}
\hline \multicolumn{1}{|c|}{ Chain } & p1 & p2 & p3 & p4 & P5 \\
\hline Arby's & 1.017 & 0.995 & 0.976 & 1.031 & 1.082 \\
Dairy Queen & 1.005 & 0.993 & 1.062 & 1.065 & 1.062 \\
Dairy Queen Brazier & 0.813 & 0.901 & 1.092 & 1.145 & 0.868 \\
KFC & 0.869 & 0.954 & na & 0.868 & 1.000 \\
Little Caesar's & 1.000 & 1.000 & 1.016 & 1.000 & 1.014 \\
Mc Donald's & 0.960 & 0.953 & 0.944 & 0.991 & 0.972 \\
Rax & 1.008 & 1.024 & 0.985 & 0.985 & 0.981 \\
\hline
\end{tabular}

2. Metropolitan Detroit Area: Fall 1991

\begin{tabular}{|l|ccccc|}
\hline \multicolumn{1}{|c|}{ Chain } & $\mathrm{p}_{1}$ & $\mathrm{p} 2$ & $\mathrm{p} 3$ & $\mathrm{p} 4$ & $\mathrm{p} 5$ \\
\hline Arby's & 1.004 & 0.977 & 1.062 & 0.916 & 1.038 \\
Baskin Robbins & 1.033 & 1.141 & 1.086 & 1.077 & 1.030 \\
Burger King & 0.991 & 0.974 & 0.953 & 1.026 & 1.036 \\
Domino's & 0.988 & 0.990 & 1.034 & 1.024 & 1.052 \\
KFC & 0.991 & 1.065 & $\mathrm{na}$ & 0.989 & 0.946 \\
Little Caesar's & 1.021 & 1.019 & 1.028 & 1.009 & 1.006 \\
Mc Donald's & 0.968 & 0.957 & 0.930 & 0.934 & 0.882 \\
Pizza Hut & 1.000 & 1.003 & 1.000 & 0.964 & 1.000 \\
Wendy's & 1.019 & 1.003 & 0.987 & 0.932 & 0.994 \\
\hline
\end{tabular}

3. Metropolitan Detroit Area : Fall 1993

\begin{tabular}{|l|ccccc|}
\hline \multicolumn{1}{|c|}{ Chain } & $\mathrm{p}_{1}$ & $\mathrm{p} 2$ & $\mathrm{p} 3$ & $\mathrm{p} 4$ & $\mathrm{p} 5$ \\
\hline Arby's & 1.006 & 0.970 & $\mathrm{na}$ & 0.884 & 1.061 \\
Baskin Robbins & 1.006 & $\mathrm{na}$ & 1.025 & $\mathrm{na}$ & 0.947 \\
Burger King & 0.919 & 1.014 & 1.069 & $\mathrm{na}$ & 1.048 \\
KFC & 0.993 & $\mathrm{na}$ & 0.972 & na & 0.945 \\
Little Caesar's & 1.026 & 1.009 & 0.995 & 0.954 & 1.054 \\
Mc Donald's & 1.000 & 1.014 & 1.025 & 1.085 & 0.962 \\
Pizza Hut & 1.000 & 1.000 & 1.000 & 1.000 & 0.985 \\
Ponderosa & 0.900 & 1.063 & 1.203 & 1.000 & 0.952 \\
Wendy's & 1.028 & 1.042 & 1.008 & 0.986 & 1.012 \\
\hline
\end{tabular}


a total of 13 franchise chains are included in the sample. Note that the criterion used for inclusion of data from a chain in the regressions is identical to what was done to generate Table 6 , namely a given franchised chain from a given survey was included in the analysis if at least one outlet of each type had given data on prices for that firm in that survey. ${ }^{39}$ The $X_{s j h k}$ 's are restaurant or market-specific variables. These include the (log of) population, the (log of) median income, the percentage of the population that is black, the (log of) the total number of restaurants in the zip code where restaurant $h$ is located, and the number of restaurants from the same chain in the same zip code. ${ }^{40}$ They also include the number of years that the restaurant has been in existence, and the number of seats in the restaurant. ${ }^{41}$ These last two variables are included to control for potential cost differences among units. ${ }^{42}$

As noted by Barron and Umbeck (1984) and Shepard (1993), the test implied by the above regression is quite stringent. Price differences between restaurants operated under the two types of organizational forms are underestimated by the calculation of the difference between any price and the mean price as the mean is determined by the prices in both types of units. In that sense, the test is biased against a finding of significant price differences. In addition, if prices in franchised units were very different from what franchisors consider optimal, franchising would become too costly and franchisors would choose to operate as corporate chains. ${ }^{43}$ And to the extent that corporate and franchised restaurants compete with each other at least in some markets, the potential gap between their prices will be further narrowed. All three of these effects reduce the likelihood that we can observe significant differences in prices for the two types of restaurants.

The results from the regressions are shown in Table 7. The first two columns in the table give results for the overall sample. The next two columns are based on the

39 Results were the same when only firms with at least two units of each type (as in Table 3) were included in the analyses.

40 The logarithmic form was used whenever the effect of a variable on the price difference was expected to be concave.

41 While the questionnaire in Appendix B is vague as to what the "Number of years at location" means, it was made quite clear to the interviewers that they should ask how long the restaurant has been operating at this specific address.

42 Unfortunately, as noted earlier, the number of seats does not represent a good measure of capacity in the pizza industry. Because we could not obtain an alternative measure, the sample simply excludes the pizza chains when capacity is used as an explanatory variable.

43 I thank Andrea Shepard for making this point. 
Table 7

OLS Results on Price Differences

\begin{tabular}{|c|c|c|c|c|c|c|}
\hline \multirow{2}{*}{$\begin{array}{c}\text { Independent } \\
\text { Variables }\end{array}$} & \multicolumn{6}{|c|}{ Dependent $\mathrm{Var}=100 *\left(\mathrm{P}_{\mathrm{ijhk}}-\mathrm{MeanP}_{\mathrm{ijk}}\right) / \mathrm{Mean} \mathrm{P}_{\mathrm{ij} \mathrm{k}}$} \\
\hline & 1 & 2 & 3 & 4 & 5 & 6 \\
\hline Corporate Dummy & $\begin{array}{l}-0.57 \\
(-1.32)\end{array}$ & $\begin{array}{l}-0.52 \\
(-1.17)\end{array}$ & $\begin{array}{l}-1.22 * \\
(-2.39)\end{array}$ & $\begin{array}{l}-1.09^{*} \\
(-2.02)\end{array}$ & $\begin{array}{l}-2.12^{* *} \\
(-3.20)\end{array}$ & $\begin{array}{l}-2.08^{* *} \\
(-3.04)\end{array}$ \\
\hline Log Population & & $\begin{array}{l}0.95^{+} \\
(1.96)\end{array}$ & & $\begin{array}{l}1.22 * \\
(2.25)\end{array}$ & & $\begin{array}{c}0.47 \\
(0.75)\end{array}$ \\
\hline Log Median Income & & $\begin{array}{l}-2.34 \\
(-1.13)\end{array}$ & & $\begin{array}{l}-3.45 \\
(-1.47)\end{array}$ & & $\begin{array}{c}1.74 \\
(0.55)\end{array}$ \\
\hline$\%$ Below Poverty & & $\begin{array}{c}-0.05 \\
(-1.11)\end{array}$ & & $\begin{array}{l}-0.10^{+} \\
(-1.77)\end{array}$ & & $\begin{array}{c}0.02 \\
(0.32)\end{array}$ \\
\hline $\begin{array}{l}\text { Log \# of Restaurants } \\
\text { in zip code }\end{array}$ & & $\begin{array}{l}-0.12 \\
(-0.17)\end{array}$ & & $\begin{array}{l}-0.05 \\
(-0.11)\end{array}$ & & $\begin{array}{c}0.72 \\
(1.14)\end{array}$ \\
\hline $\begin{array}{l}\text { No. of Restaurants } \\
\text { from same chain }\end{array}$ & & $\begin{array}{l}-0.36 \\
(-1.31)\end{array}$ & & $\begin{array}{l}-0.58+ \\
(-1.69)\end{array}$ & & $\begin{array}{l}-1.02 * \\
(-2.46)\end{array}$ \\
\hline \% Black & & $\begin{array}{l}-0.001 \\
(-0.10)\end{array}$ & & $\begin{array}{l}0.01 \\
(.93)\end{array}$ & & $\begin{array}{c}0.02 \\
(1.41)\end{array}$ \\
\hline Highway Location & & $\begin{array}{l}-0.14 \\
(-0.28)\end{array}$ & & $\begin{array}{c}0.74 \\
(1.31)\end{array}$ & & $\begin{array}{l}2.06 * * \\
(2.63)\end{array}$ \\
\hline Business District & & $\begin{array}{l}-0.50 \\
(-1.04)\end{array}$ & & $\begin{array}{l}-0.95^{+} \\
(-1.67)\end{array}$ & & $\begin{array}{c}-0.18 \\
(-0.23)\end{array}$ \\
\hline Mall Location & & $\begin{array}{c}0.81 \\
(0.60)\end{array}$ & & $\begin{array}{c}0.42 \\
(0.27)\end{array}$ & & $\begin{array}{c}1.55 \\
(0.94)\end{array}$ \\
\hline Inner City Location & & $\begin{array}{l}-1.91 * \\
(-2.54)\end{array}$ & & $\begin{array}{l}-2.04^{*} \\
(-2.26)\end{array}$ & & $\begin{array}{c}0.51 \\
(0.45)\end{array}$ \\
\hline Years & & & $\begin{array}{c}0.01 \\
(0.48)\end{array}$ & $\begin{array}{c}0.02 \\
(0.69)\end{array}$ & $\begin{array}{l}0.05^{+} \\
(1.87)\end{array}$ & $\begin{array}{c}0.04 \\
(1.25)\end{array}$ \\
\hline Seats & & & & & $\begin{array}{l}-0.004 \\
(-0.55)\end{array}$ & $\begin{array}{l}-0.001 \\
(-0.18)\end{array}$ \\
\hline Number of Obs. & 1580 & 1580 & 1117 & 1117 & 511 & 511 \\
\hline$F$ (slopes $=0$ ) & 0.47 & 0.96 & 0.79 & $1.49 *$ & $1.72 *$ & $1.99 * *$ \\
\hline $\mathrm{R}^{2}$ & 0.004 & 0.02 & 0.01 & 0.03 & 0.05 & 0.09 \\
\hline
\end{tabular}

Constant terms and chain and survey dummy variables included in all regressions.

Two-tail t-statistics in parentheses: ${ }^{* *}=$ Sign. at $0.01, *=$ Sign. at $0.05,+=$ Sign . at 0.10 . 
subsample of restaurants that provided information about how long they have been in business, while the last two columns is for the subsample that gave information on both the number of years in business and the number of seats in the restaurant. Despite the stringency of the test, prices in company-owned units are slightly below those in franchised units. This result, which is robust to the inclusion and exclusion of various regressors, is especially interesting in the context of fast-food franchising as the existing literature suggests that per-unit costs are higher in corporate units than in franchised units. ${ }^{44}$

The results in Table 7 are consistent with those on price dispersion in that they confirm the existence of a systematic price differential between franchised and corporate restaurants. The fact that prices are lower in corporate units suggests that double marginalization and/or positive externalities, but not franchisor opportunism, are the cause of at least some of the price dispersion. As for other variables, very few have any influence on observed price differences. Of the market characteristics in the data, only population and the number of restaurants from the same chain in the same zip code have a consistent and mostly significant effect on prices, in the expected directions. For the rest, the effects are not consistent across the three subsamples. In particular, neither the number of years in business or the size of the restaurant has any effect on prices. This implies that the change in the effect of the corporate dummy (and in its significance level) from one set of regressions to another is attributable to changes in the sample itself. Regressions on the two subsamples without the "years" and "seats" variables confirmed this. In fact, further investigation revealed that removing a single restaurant chain (Little Ceasar's) from the overall sample was sufficient to make the coefficients for the corporate dummy significant at the $5 \%$ level. $^{45}$

\subsubsection{Endogeneity}

Equation (4.2) assumes that the decision to franchise or operate directly is exogenously given. This is consistent with the notion that at the time the pricing decisions are made, the decision as to which type of contract the unit operates under

44 See Shelton (1967) and Krueger (1991).

45 Note that Little Ceasar's is excluded from the "seats" subsample because it is a pizza chain. It is not, however, excluded from the "years" sample. 
has already been made. In other words, the timing of these decisions is such as to rule out a causality from pricing to the form of the contract. However, one cannot rule out the possibility that some underlying phenomenon (market or unit characteristics) that has led to the choices of contractual form under which a restaurant operates is also influencing the level of prices chosen at this restaurant. For example, if units located on highways are more subject to free-riding - as has been argued e.g. by Klein (1980) and Brickley and Dark (1987) - franchisors may want to operate them directly. At the same time, because these benefit from some degree of market power, they can charge higher prices than restaurants facing more intense competition. Hence the same phenomenon, highway location, might simultaneously imply a greater likelihood of a restaurant being corporate, and higher prices.

In those cases where the underlying variable is observable, including it in (4.2) will eliminate the bias in the estimated effect of the franchise vs. company-owned decision on prices in the OLS equations (assuming uncorrelated error terms). The estimates found in columns 2, 4 and 6 in Table 7 in that sense already correct for the potential effect of a number of such observable characteristics of restaurants. If however there are unobservable underlying variables that affect both the form of organization and prices, we have

$$
\frac{P_{i j h k}-\operatorname{Mean} P_{i j k}}{M e a n P_{i j k}}=\beta_{0}+\beta_{1} \operatorname{Corp}_{j h k}+\cdots+\epsilon_{i j h k}
$$

and

$$
\operatorname{Cor} p_{j h k}^{*}=\sum_{r=1}^{R} \theta_{r} X_{j h k}+\mu_{j h k}
$$

where $\operatorname{Corp}_{j h k}=1$ if $\operatorname{Corp}_{j h k}^{*}>0$ and $\operatorname{Corp}_{j h k}=0$ if $\operatorname{Corp}_{j h k}^{*}<0$, and where some (or all) of the $X_{j h k}$ variables may be included in (4.3). Missing unobservable variables in both equations imply correlated error terms that make the OLS estimates of equation (4.3) biased. Heckman's two-stage estimation procedure can be used to eliminate this bias. This procedure consists of first estimating a probit regression on the franchise vs. corporate decision, the fitted values of which are then used in the second stage as an instrument for Corp in equation (4.3). But while this estimator is consistent, it is not efficient. For that reason, the maximum likelihood estimator is used below.

The probit estimates for equation (4.4) are reported in Table 8. The specification of these regressions was chosen to maximize the predictive power of the regressions, 
Table 8

PROBIT Results on the Corporate Vs. Franchised Decision

\begin{tabular}{|c|c|c|c|}
\hline \multirow{2}{*}{$\begin{array}{c}\text { Independent } \\
\text { Variables }\end{array}$} & \multicolumn{3}{|c|}{ Dependent Var $=$ Corporate Dummy } \\
\hline & 1 & 2 & $3(1)$ \\
\hline \multirow[t]{2}{*}{ Log population } & $0.20^{*}$ & $0.34^{* *}$ & $0.32 *$ \\
\hline & $(2.18)$ & $(3.16)$ & $(2.19)$ \\
\hline \multirow[t]{2}{*}{$\%$ Black } & $-0.01 * *$ & $-0.01 * *$ & $-0.01 * *$ \\
\hline & $(-4.46)$ & $(-3.42)$ & $(-4.55)$ \\
\hline \multirow[t]{2}{*}{ Log median income } & $-1.26 * *$ & $-1.09 *$ & -0.16 \\
\hline & $(-2.97)$ & $(-2.14)$ & $(-0.16)$ \\
\hline \multirow[t]{2}{*}{$\%$ Below poverty } & $-0.02 *$ & $-0.03 * *$ & -0.02 \\
\hline & $(-2.49)$ & $(-2.78)$ & $(-0.95)$ \\
\hline \multirow[t]{2}{*}{ Log \# of restaurants in zip code } & 0.05 & 0.07 & 0.21 \\
\hline & $(0.61)$ & $(0.62)$ & $(1.29)$ \\
\hline \# of restaurants from the & $0.18 * *$ & $0.45 * *$ & 0.10 \\
\hline same chain in zip code & $(3.33)$ & $(6.03)$ & $(0.98)$ \\
\hline \multirow[t]{2}{*}{ Highway location } & $0.32 * *$ & $0.22^{+}$ & -0.35 \\
\hline & $(3.18)$ & $(1.86)$ & $(-1.62)$ \\
\hline \multirow[t]{2}{*}{ Mall location } & 0.21 & -0.47 & -0.21 \\
\hline & $(0.83)$ & $(-1.61)$ & $(-0.45)$ \\
\hline \multirow[t]{2}{*}{ Inner city location } & 0.21 & $0.57 * *$ & $0.61^{+}$ \\
\hline & $(1.30)$ & $(2.91)$ & $(1.78)$ \\
\hline \multirow[t]{2}{*}{ Years in existence } & & $0.03 * *$ & $0.04 * *$ \\
\hline & & $(5.25)$ & $(4.08)$ \\
\hline \multirow[t]{2}{*}{ \# of Seats } & & & $0.01 * *$ \\
\hline & & & $(4.07)$ \\
\hline Number of obs. at 0 & 711 & 498 & 243 \\
\hline Number of obs. at 1 & 869 & 619 & 268 \\
\hline$\%$ Correctly predicted & 78.2 & 81.1 & 80.6 \\
\hline Chi-squared (slopes $=0$ ) & $623.7 * *$ & $515.2 * *$ & $256.6 * *$ \\
\hline
\end{tabular}

Constant term and chain and survey dummy variables included in all regressions.

(1): Excludes Pizza chains for which seats is not a good measure of size.

Asymptotic 2-tail t-statistics in parentheses: ${ }^{* *}=$ Sign. at $0.01,{ }^{*}=$ Sign. at $0.05,+=$ Sign. at 0.10 . 
thereby increasing the validity of the instrument. The results in Table 8 show that the explanatory variables capture a good proportion of the variance in the dependent variable in the sense that the estimated equations predict the correct outcome for a large proportion of the observations, much more so than a rule of always choosing the most frequent outcome. In that sense, our instrument for the Corp variable is quite satisfactory.

Though this is not the focus of the present paper, it is also worth noting from Table 8 that older and larger restaurants are more likely to be operated corporately than under a franchise agreement, as are restaurants located in higher population areas, restaurants in "inner city" locations and restaurants located in zip code areas with more restaurants from the same chain. ${ }^{46}$ On the other hand, the percentage of blacks in the population, median income and the proportion of the population living below the poverty level significantly increase the likelihood of franchising. I come back to some of these effects below.

The maximum likelihood estimates for the price differential equations are found in Table 9. They show that there is in fact no selection problem in the data: The estimates of $\rho$, the correlation between the error terms in equations (4.3) and (4.4), are never significant, and so the estimates in Table 7 and 9 are very similar. Also, as above, the negative effect of the corporate dummy variable in the overall sample, and its significance level, increase quite dramatically when the "Little Ceasar's" restaurant chain is excluded from the estimations. Hence for all chains but this one, corporate units clearly have lower prices than franchised units. The difference, as expected, is relatively small - in the order of 1 to $2 \%$ on average around the overall mean price but it is significant.

Lower prices in corporate than in franchised stores, combined with the relationship found between price dispersion and the use of franchising, suggest that double marginalization or horizontal externalities are the source of price differentials. The fact that the royalty rate has a positive effect on the extent of price dispersion especially for firms that franchise less than $50 \%$ of their units - gives further support for the double marginalization argument.

46 Some of the variables "lose" their effects in column 3 most likely because years and seats are both included in this column, and these variables are correlated with variables such as highway location and median income because markets with these characteristics will be the first to be developed. 
Table 9

ML Estimates of the Selection Model for Price Differences

\begin{tabular}{|c|c|c|c|c|c|c|}
\hline \multirow{2}{*}{$\begin{array}{c}\text { Independent } \\
\text { Variables } \\
\end{array}$} & \multicolumn{6}{|c|}{ Dependent $\operatorname{Var}=100^{*}\left(\mathrm{P}_{\mathrm{ijhk}}-\mathrm{MeanP}_{\mathrm{ijk}}\right) / \mathrm{Mean} \mathrm{P}_{\mathrm{ijk}}$} \\
\hline & 1 & 2 & 3 & 4 & 5 & 6 \\
\hline Corporate Dummy & $\begin{array}{c}-0.54 \\
(-1.16)\end{array}$ & $\begin{array}{c}-0.48 \\
(-0.98)\end{array}$ & $\begin{array}{l}-1.23 * \\
(-2.17)\end{array}$ & $\begin{array}{l}-1.07+ \\
(-1.85)\end{array}$ & $\begin{array}{l}-2.14^{* *} \\
(-2.96)\end{array}$ & $\begin{array}{l}-2.10^{* *} \\
(-2.81)\end{array}$ \\
\hline Log Population & & $\begin{array}{l}0.96+ \\
(1.86)\end{array}$ & & $\begin{array}{l}1.23^{*} \\
(2.13)\end{array}$ & & $\begin{array}{c}0.50 \\
(0.65)\end{array}$ \\
\hline Log Median Income & & $\begin{array}{c}-2.57 \\
(-1.10)\end{array}$ & & $\begin{array}{c}-3.49 \\
(-1.34)\end{array}$ & & $\begin{array}{c}1.79 \\
(0.42)\end{array}$ \\
\hline$\%$ Below poverty & & $\begin{array}{c}-0.06 \\
(-1.15)\end{array}$ & & $\begin{array}{c}-0.10 \\
(-1.63)\end{array}$ & & $\begin{array}{c}0.03 \\
(0.31)\end{array}$ \\
\hline $\begin{array}{l}\text { Log \# of restaurants } \\
\text { in zip code }\end{array}$ & & $\begin{array}{c}-0.10 \\
(-0.25)\end{array}$ & & $\begin{array}{c}-0.06 \\
(-0.12)\end{array}$ & & $\begin{array}{c}0.70 \\
(1.06)\end{array}$ \\
\hline No. of restaurants & & -0.36 & & -0.57 & & $-1.01^{*}$ \\
\hline from same chain & & $(-1.20)$ & & $(-1.52)$ & & $(-2.05)$ \\
\hline \% Black & & $\begin{array}{c}-0.01 \\
(-0.09)\end{array}$ & & $\begin{array}{c}0.01 \\
(1.14)\end{array}$ & & $\begin{array}{c}0.02 \\
(1.30)\end{array}$ \\
\hline Highway location & & $\begin{array}{c}-0.14 \\
(-0.28)\end{array}$ & & $\begin{array}{c}0.75 \\
(1.35)\end{array}$ & & $\begin{array}{l}2.09 * \\
(2.22)\end{array}$ \\
\hline Business district & & $\begin{array}{c}-0.52 \\
(-1.02)\end{array}$ & & $\begin{array}{c}-0.95 \\
(-1.64)\end{array}$ & & $\begin{array}{c}-0.21 \\
(-0.26)\end{array}$ \\
\hline Mall location & & $\begin{array}{c}0.69 \\
(0.41)\end{array}$ & & $\begin{array}{c}0.39 \\
(0.12)\end{array}$ & & $\begin{array}{c}1.45 \\
(0.66)\end{array}$ \\
\hline Inner city location & & $\begin{array}{l}-1.93^{*} \\
(-2.35)\end{array}$ & & $\begin{array}{l}-2.04^{*} \\
(-2.34)\end{array}$ & & $\begin{array}{c}0.51 \\
(0.42)\end{array}$ \\
\hline Years & & & $\begin{array}{c}0.01 \\
(0.47)\end{array}$ & $\begin{array}{c}0.02 \\
(0.63)\end{array}$ & $\begin{array}{l}0.05^{*} \\
(2.04)\end{array}$ & $\begin{array}{c}0.04 \\
(1.15)\end{array}$ \\
\hline Seats & & & & & $\begin{array}{l}-0.004 \\
(-0.51) \\
\end{array}$ & $\begin{array}{r}-0.002 \\
(-0.23) \\
\end{array}$ \\
\hline Number of obs. & 1580 & 1580 & 1117 & 1117 & 511 & 511 \\
\hline Rho & $\begin{array}{c}0.06 \\
(0.82)\end{array}$ & $\begin{array}{c}0.07 \\
(0.87)\end{array}$ & $\begin{array}{c}-0.01 \\
(-0.07)\end{array}$ & $\begin{array}{c}0.01 \\
(0.19)\end{array}$ & $\begin{array}{c}0.06 \\
(0.45)\end{array}$ & $\begin{array}{c}0.10 \\
(0.74)\end{array}$ \\
\hline LLF & -6116 & -6107 & -4264 & -4250.8 & -1850 & -1838 \\
\hline
\end{tabular}

Constant terms and chain and survey dummy variables included.

Asymptotic 2-tail t-statistics in parentheses: ${ }^{* *}=$ Sign. at $0.01,{ }^{*}=$ Sign. at $0.05,+=$ Sign. at 0.10 . 
Having established the above result, it is interesting now to revisit the effect on price differences of some of the demographic variables included in the present study in light of recent results obtained by Graddy (1995). Her work suggests that prices are higher in areas where the proportion of blacks in the population is greater. No such systematic effects are found here. However, from Table 8, the higher the proportion of blacks in the population, the higher the probability that a unit will be franchised. And franchised units do price higher than corporate units - an effect that Graddy also finds in her data. Thus the results here suggest that the higher prices found for predominantly black areas in Graddy (1995) are due mainly to a failure to endogenize the organizational form decision. ${ }^{47}$ Of course, one could argue that restaurants in mostly black areas are franchised because the chain knows that these will charge higher prices. But this presumes that the franchise chain can extract the profits thus generated, which is unlikely with uniform franchise contracts. Furthermore, it again does not seem consistent with the practice of putting downward pressure on franchisee prices. An alternative explanation for franchises in predominantly black areas would be that the owners of these are likely to be from the area and have a better working knowledge of his or her market. The fact that African-American franchisees complain about being sold units mostly in predominantly black areas is consistent with the latter explanation. ${ }^{48}$

\section{Conclusion}

This paper has shown the existence of price dispersion in fast-food franchising. It has also established the fact that this price dispersion is related to the extent to which a chain is involved in franchising. This relationship generally takes the form of an inverted "U" combined with a greater degree of price dispersion for fully franchised firms than for fully corporate chains. These patterns suggest that 1) franchisors are not able to control franchisees' prices indirectly to the same extent that they control company-owned unit prices and 2) the prices in franchised and corporate units are

47 Interestingly, an inner city location, as defined here, is more likely to be corporate than franchised. This may be because once population, income and the proportion of blacks are controlled for, this variable captures some "geographic density" effect, just like the number of restaurants in the same zip code does. Density typically increases the likelihood that a unit is corporately owned and operated. It also reduces prices, as both of these variables do in Tables 7 and 9 .

48 Thompson (1992), at 60 . 
systematically different, leading to the inverted " $U$ " shape between price dispersion and the extent of franchising.

$\Lambda$ closer look at price differentials themselves revealed that prices in corporate units are below those in franchised restaurants. This suggests that the reason behind price differentials is not franchisor opportunism, leaving double marginalization and the potential existence of horizontal externalities as the main explanations for the observed price patterns. In other words, the results suggest that the downward pressure that franchisors have been accused of putting on franchisees prices is not due to their desire to maximize individual franchised unit sales rather than profits, but rather arises from their desire either to reduce the franchisee's use of market power, or to internalize a sales externality due to the tradename. In either case, it is noteworthy that consumers would benefit from the relaxation of the maximum resale price maintenance rules embedded in U.S. Antitrust laws. Given this, it would be useful to extend this work to study the pricing policies of franchisors in jurisdictions where maximum resale price maintenance is not illegal, such as the United Kingdom and Canada, and see whether one finds franchisors dictating prices more often in these countries, and ultimately whether this has an effect on the amount of price dispersion or price differentials between company-owned and franchised units in these markets. Still, the finding that prices are higher in franchised restaurants than in companyowned restaurants is consistent with the existing empirical literature, which as noted earlier, covered different types of businesses and different jurisdictions (Slade (1995) in particular is concerned with beer distribution in the U.K.). In that sense, this result seems quite robust. 


\section{REFERENCES}

Barron, John M. and John R. Umbeck, (1984), "The Effects of Different Contractual Arrangements: The Case of Retail Gasoline Markets", Journal of Law and Economics,27, 313-328.

Blair, Roger D. and David L. Kaserman, (1982), "Optimal Franchising", Southern Economic Journal, 494-504.

Bonnano, Giacomo and John Vickers, (1988), "Vertical Separation", The Journal of Industrial Economics, 36, 257-265.

Borenstein, S. and N.L. Rose, (1991), "Competition and Price Dispersion in the U.S. Airline Industry", NBER Working Paper No. 3785.

Card, David and Alan B. Krueger, (1994), "Minimum Wages and Employment: A Case Study of the Fast Food Industry in New Jersey and Pennsylvania," The American Economic Review, 84, 772-793.

Caves, Richard E. and William F. Murphy II, (1976), "Franchising: Firms, Markets, and Intangible Assets", Southern Economic Journal, 42, April, 572-586.

Dnes, Antony W. 1992. Franchising: A Case-study Approach. Aldershot, England: Avebury.

Entrepreneur Magazine. Annual Franchise 500. Jan. 1992, Jan. 1993.

Franchise Update, "The Encroachment Dilemma", 2nd quarter, 1994.

Gal-Or, E., (1991), "Optimal Franchising in Oligopolistic Markets with Uncertain Demand", International Journal of Industrial Organization, 9, 343-364.

Gallini, Nancy T. and Nancy A. Lutz (1992), "Dual Distribution and Royalty Fees in Franchising", Journal of Law, Economics, \& Organization, 8, 471-501.

Graddy, K. (1995), "Do Fast-Food Chains Price Discriminate on the Race and Income Characteristics of an Area," mimeo, Jesus College, Oxford University.

Hadfield, Gillian K. (1990), "Problematic Relations: Franchising and the Law of Incomplete Contracts," 42 Stanford Law Review 927-992.

Hadfield, Gillian K., (1991), "Credible Spatial Preemption through Franchising", Rand Journal of Economics, 22, 531-543.

Heckman, J., (1978), "Dummy Endogenous Variables in a Simultaneous Equation System", Econometrica, 46, 931-960.

Hunt, S. D., and J. R. Nevin. 1975. "Tying Agreements in Franchising," 39 Journal of Marketing 20-26.

Klein, B., (1980), "Transaction Costs Determinants of "Unfair" Contractual Arrangements", American Economic Review, 70, 356-362. 
Klein, B. and K.M. Murphy (1988), "Vertical Restraints as Contract Enforcement Mechanisms", Journal of Law and Economics, 31, 265-297.

Klein, B. and L.F. Saft, (1985), "The Law and Economics of Franchise Tying Contracts", Journal of Law and Economics, 28, 345-361.

Krueger, A. B., (1991), "Ownership, Agency and Wages: An Examination of the Fast Food Industry," Quarterly Journal of Economics, 106, 75-101.

Lafontaine, Francine. (1992a), "Contract Theory and Franchising: Some Empirical Results," Rand Journal of Economics, 23, 263-283.

Lafontaine, F., (1992b), "How and Why do Franchisors do What They do: A Survey Report," in P. Kaufmann, ed., Franchising: Passport for Growth 6 World of Opportunity. Sixth Annual Proceedings of the Society of Franchising, International Center for Franchise Studies, University of Nebraska.

Love, J.F., (1986), McDonald's: Behind the Arches, Bantam Books, Inc. New York.

Maddala, G.S., Limited-Dependent and Qualitative Variables in Econometrics, Cambridge University Press, New York, 1983.

Masten, S.E., J.W. Meehan, Jr and E.A. Snyder, (1991), "The Costs of Organization," Journal of Law, Economics, \& Organization, 7, 1-25.

McAfee, R.P. and M. Schwartz, (1994), "Multilateral Vertical Contracting: Opportunism, Nondiscrimination, and Exclusivity", American Economic Review, bf 84, 210-230.

Minkler, A.P., (1990), "An Empirical Analysis of a Firm's Decision to Franchise", Economics Letters, 34, 77-82.

Minkler, A.P., (1992), "Why Firms Franchise: A Search Cost Theory", Journal of Institutional and Theoretical Economics, 148, 240-259.

Ozanne, U.B. and S.D. Hunt, (1971), The Economic Effect of Franchising, U.S. Senate, Select Committee on Small Business, Washington, Gov. Printing Office.

Pratt, J.W., Wise, D.A. and R. Zeckhauser, (1979), "Price Differences in Almost Competitive Markets," Quarterly Journal of Economics, 189-211.

Romano, R.E., (1994), "Double Moral Hazard and Resale Price Maintenance," Rand Journal of Economics, 25, 455-466.

Sass, T.R. and D.S. Saurman, (1993), "Mandated Exclusive Territories and Economic Efficiency: An Empirical Analysis of the Malt-Beverage Industry," Journal of Law and Economics, 36, 153-177.

Schmidt, Torsten, (1994), "An Analysis of Intrabrand Competition in the Franchise Industry," Review of Industrial Organization, 9, 293-310. 
Shelton, J., (1967), "Allocative Efficiency vs. "X-Efficiency": Comment", American Economic Review, December, 1252-1258.

Shepard, A., (1993), "Contractual Form, Retail Price, and Asset Characteristics in Gasoline Retailing," Rand Joumal of Economics, 24, 58-77.

Slade, M. (1993), "Strategic Motives for Vertical Separation: Evidence from Gasoline", Department of Economics Working Paper No. 93-12, UBC.

Slade, M., (1995a), "Beer and the Tie: Did Divestiture Cause Higher Prices?", mimeo, Dept. of Economics, University of British Columbia.

Slade, M. (1995b), "Multitask Agency and Contract Choice: An Empirical Assessment", International Economic Review, forthcoming.

Smith II, Richard L., (1982), "Franchise Regulation: An Economic Analysis of State Restrictions on Automobile Distribution", Journal of Law and Economics, 25, $125-157$.

Thompson, Kevin D., (1992), "Driving for Diversity," Black Enterprise, Sept. 49-60. 


\section{Appendix A}

Pricing Policies for Corporate-Owned Restaurants According to Company Head Offices

\begin{tabular}{|c|c|c|c|c|}
\hline & \multicolumn{4}{|c|}{ Prices in corporate restaurants are: } \\
\hline Chain: & $\begin{array}{l}\text { Identical across } \\
\text { all restaurants } \\
\text { nationally }\end{array}$ & $\begin{array}{l}\text { Identical within } \\
\text { regions, but } \\
\text { variable across } \\
\text { regions } \\
\end{array}$ & $\begin{array}{l}\text { Allowed to vary } \\
\text { completely }\end{array}$ & $\begin{array}{l}\text { No answer } \\
\text { /Don't know }\end{array}$ \\
\hline Arby's & $\sqrt{ }$ & & & \\
\hline Baskin Robbins & & & & $\sqrt{ }$ \\
\hline Burger King & & $\sqrt{ }$ & & \\
\hline Chi-Chi's & & & $\sqrt{ }$ & \\
\hline $\begin{array}{l}\text { Dairy } \\
\text { Queen/Brazier }\end{array}$ & & & $\sqrt{ }$ & \\
\hline Denny's & & $\sqrt{ }$ & & \\
\hline Domino's & & & $\sqrt{ }$ & \\
\hline Dunkin Donuts & & & & $\sqrt{ }$ \\
\hline Eat N Park & $\sqrt{ }$ & & & \\
\hline Four Star Pizza & & & & $\sqrt{ }$ \\
\hline $\mathrm{KFC}$ & & & & $\sqrt{ }$ \\
\hline Little Caesar's Pizza & & & & $\sqrt{ }$ \\
\hline Long John Silver's & & $\sqrt{ }$ & & \\
\hline McDonald's & & & $\sqrt{ }$ & \\
\hline Mr. Donut & & & & $\sqrt{ }$ \\
\hline Pizza Hut & & & $\sqrt{ }$ & \\
\hline Ponderosa & & $\sqrt{ }$ & & \\
\hline $\operatorname{Rax}$ & & $\sqrt{ }$ & & \\
\hline Roy Rogers & & & & $\sqrt{ }$ \\
\hline Subway & & & & $\sqrt{ }$ \\
\hline Taco Bell & $\sqrt{ }$ & & & \\
\hline Wendy's & & $\sqrt{ }$ & & \\
\hline
\end{tabular}




\section{Appendix B}
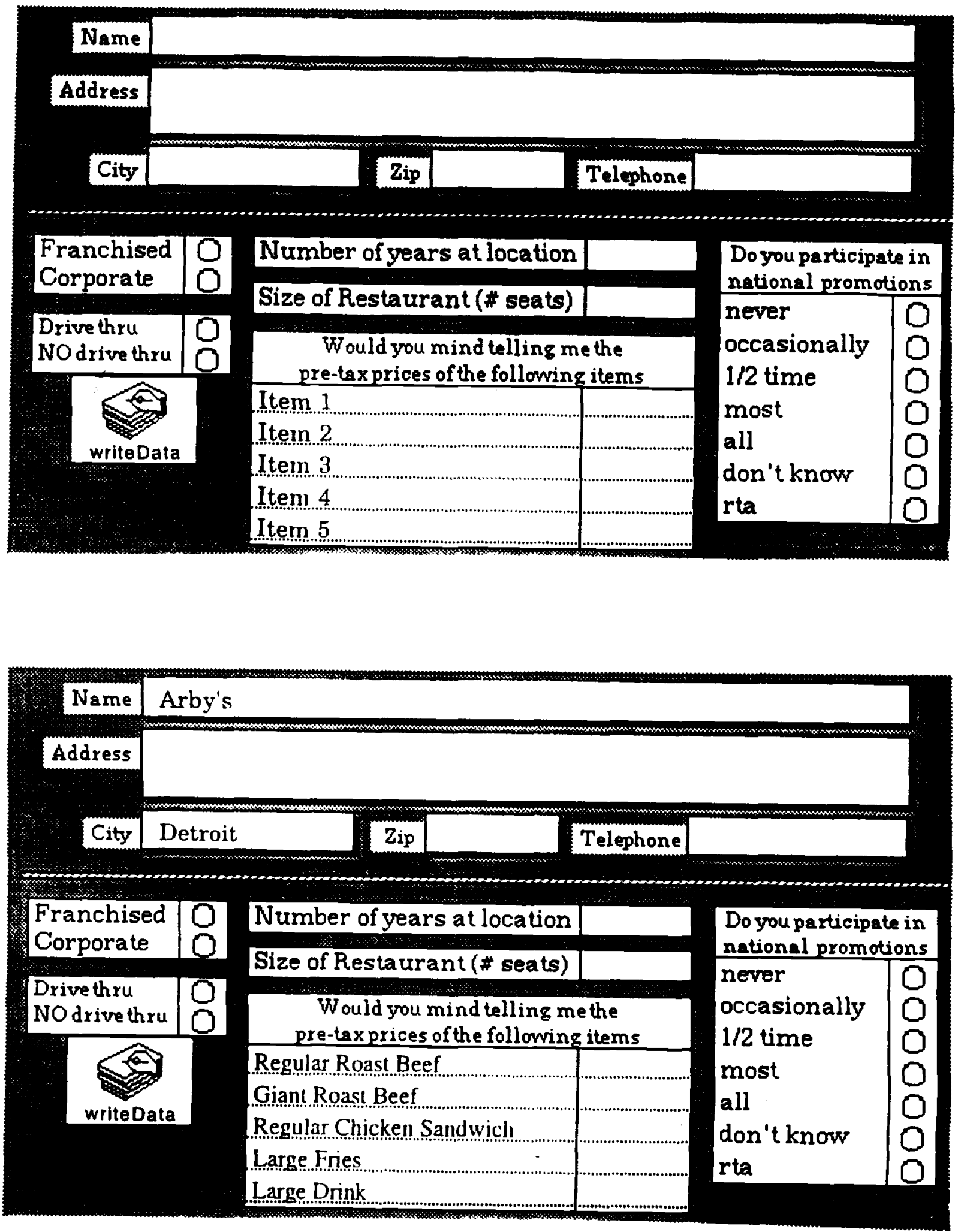


\section{Appendix C}

Table A

Chain Specific Information: 1991

\begin{tabular}{|c|c|c|c|c|c|c|}
\hline Chain: & $\begin{array}{l}\text { Years in } \\
\text { Fran- } \\
\text { chising }\end{array}$ & $\begin{array}{l}\text { Total } \\
\text { Number } \\
\text { of Units }\end{array}$ & $\begin{array}{c}\% \\
\text { Company } \\
\text { Owned }\end{array}$ & $\begin{array}{l}\text { Royalty } \\
\text { Rate }(\%)\end{array}$ & $\begin{array}{c}\text { Franchise } \\
\text { Fee } \\
(\$ 000)\end{array}$ & $\begin{array}{c}\text { Average } \\
\text { Capital } \\
\text { Required } \\
(\$ 000) \\
\end{array}$ \\
\hline Arby's & 26 & 2495 & 10.14 & $4.2-4.7$ & 31 & 687 \\
\hline Baskin Robbins & 43 & 3436 & 1.80 & $2.5-4.5$ & 0 & 142 \\
\hline Burger King & 37 & 5594 & 16.84 & 7.5 & 40 & $600^{1}$ \\
\hline Chi-Chi's & na & na & 100.00 & na & na & na \\
\hline Dairy Queen & 47 & 5303 & 0.09 & 8.5 & 30 & 595 \\
\hline Dairy Queen/Brazier & 47 & 5303 & 0.09 & 8.5 & 30 & 595 \\
\hline Denny's & 7 & 1301 & 76.17 & 6 & 35 & na \\
\hline Domino's & 24 & 5279 & 22.43 & 9.5 & 6.5 & 132 \\
\hline Dunkin Donuts & 35 & 2402 & 0.08 & 9.9 & 40 & 200 \\
\hline Eat N Park & na & na & 100.00 & na & na & na \\
\hline Four Star Pizza & 6 & 84 & 0 & 8 & 7 & 108 \\
\hline KFC & 39 & 5908 & 45.39 & 9 & 20 & 700 \\
\hline Little Caesar's Pizza & 29 & 3301 & 24.48 & 12 & 20 & 140 \\
\hline Long John Silver's & 22 & 1453 & 68.27 & 9 & 12.5 & 750 \\
\hline McDonald's & 36 & 12044 & 28.44 & 7.5 & 22.5 & 610 \\
\hline Mr. Donut & na & na & na & na & na & na \\
\hline Pizza Hut & 31 & na & na & na & na & na \\
\hline Ponderosa & 25 & 770 & 51.82 & 8 & 25 & 1050 \\
\hline $\operatorname{Rax}$ & 13 & 352 & 29.83 & 7 & 30 & 675 \\
\hline Roy Rogers & na & na & 100.00 & na & na & na \\
\hline Subway & 17 & 5777 & 0.03 & 10.5 & 10 & 54 \\
\hline Taco Bell & na & na & na & na & na & na \\
\hline Wendy's Int'l Inc. & 20 & 3448 & 28.92 & 8 & 25 & 700 \\
\hline
\end{tabular}

Notes: Roy Rogers and Eat N Park are corporate chains. Chi-Chi's is also no longer involved in franchising. Pizza Hut and Taco Bell are no longer recruiting franchisees. Mr. Donut was purchased by Dunkin Donuts around 1991.

1 : Data are for 1992. 
Table B

Chain Specific Information: 1993

\begin{tabular}{|lcccccc|}
\hline Chain: & $\begin{array}{c}\text { Years in } \\
\text { Fran- } \\
\text { chising }\end{array}$ & $\begin{array}{c}\text { Total } \\
\text { Number } \\
\text { of Units }\end{array}$ & $\begin{array}{c}\% \\
\text { Company } \\
\text { Owned }\end{array}$ & $\begin{array}{c}\text { Royalty } \\
\text { Rate }(\%)\end{array}$ & $\begin{array}{c}\text { Franchise } \\
\text { Fee } \\
(\$ 000)\end{array}$ & $\begin{array}{c}\text { Average } \\
\text { Capital } \\
\text { Required } \\
(\$ 000)\end{array}$ \\
\hline Arby's & 28 & 2603 & 10.30 & $4.2-4.7$ & 37.5 & 724 \\
Baskin Robbins & 45 & 3568 & 0.31 & $3.5-5.0$ & 0 & 165 \\
Burger King & 39 & 6700 & 14.75 & 7.5 & 40 & 6001 \\
Domino's 1 & 26 & 5154 & 16.28 & 9.5 & 6.5 & 132 \\
Dunkin Donuts & 37 & 3167 & 0.16 & $8.9-11.9$ & 40 & 400 \\
KFC & 41 & 5034 & 40.03 & $8.5-9.5$ & 25 & 700 \\
Little Caesar's Pizza & 31 & 4500 & 28.89 & 12 & 20 & 168 \\
Long John Silver's & 24 & 1453 & 68.20 & 9 & 12.5 & 650 \\
McDonald's & 38 & 13230 & 27.04 & 7.5 & 22.5 & 648 \\
Pizza Hut & 33 & $n a$ & $n a$ & $n a$ & $n a$ & na \\
Ponderosa & 27 & 770 & 46.62 & 8.8 & 30 & 1050 \\
Subway & 19 & 8103 & 0.04 & 10.5 & 10 & 70 \\
Wendy's Int'l Inc. & 22 & 4082 & 29.45 & 8 & 25 & 800 \\
\hline
\end{tabular}

Notes: Pizza Hut is no longer recruiting franchisees.

$$
\text { 1: Data are for } 1992 .
$$

